1881

\title{
The Emigrant and Sportsman in Canada
}

John J. Rowan

How does access to this work benefit you? Let us know!

Follow this and additional works at: https://commons.und.edu/settler-literature

\section{Recommended Citation}

Rowan, John J., "The Emigrant and Sportsman in Canada" (1881). Settler Literature Archive. 156.

https://commons.und.edu/settler-literature/156

This Book is brought to you for free and open access by the Department of English at UND Scholarly Commons. It has been accepted for inclusion in Settler Literature Archive by an authorized administrator of UND Scholarly Commons. For more information, please contact und.commons@library.und.edu. 


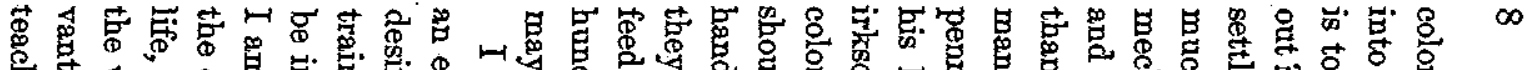
它

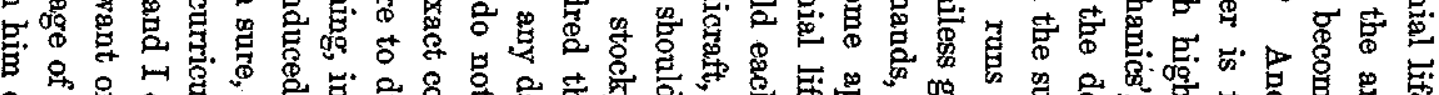

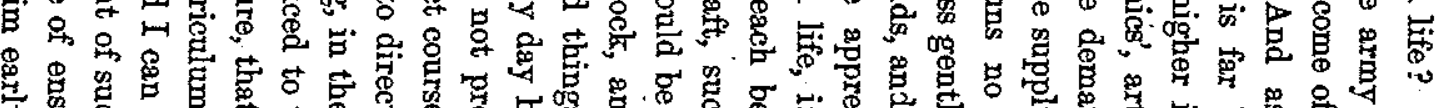

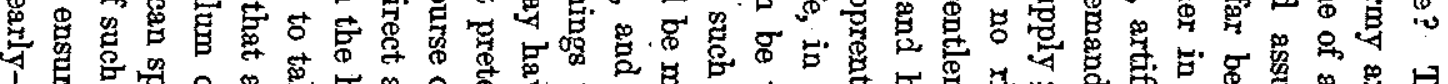

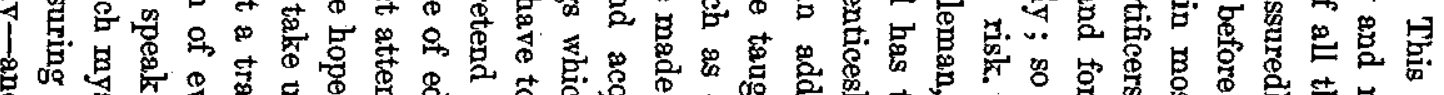

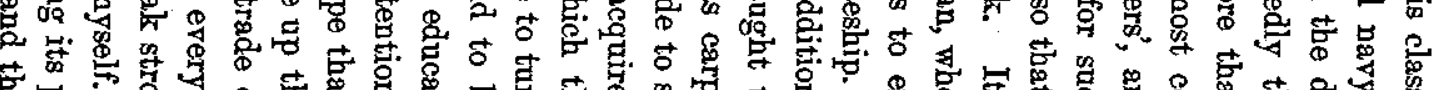

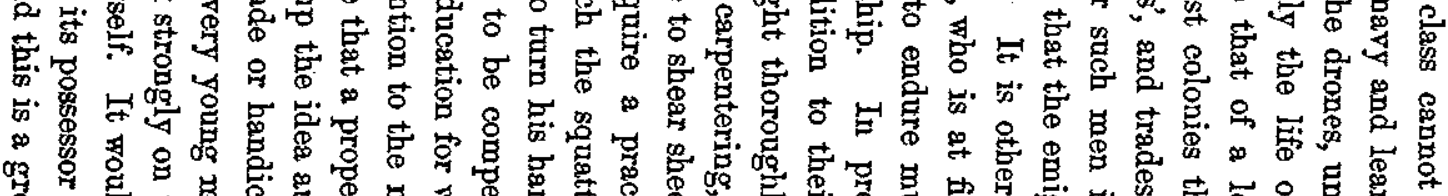

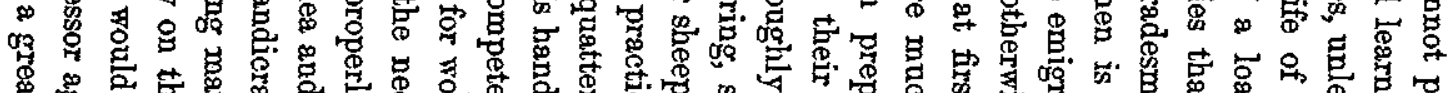

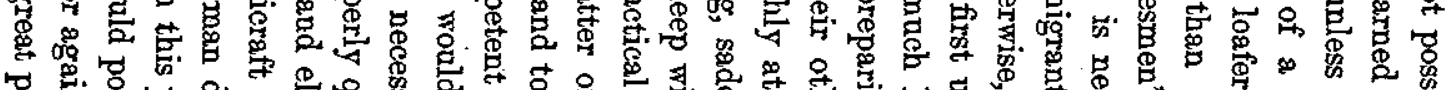

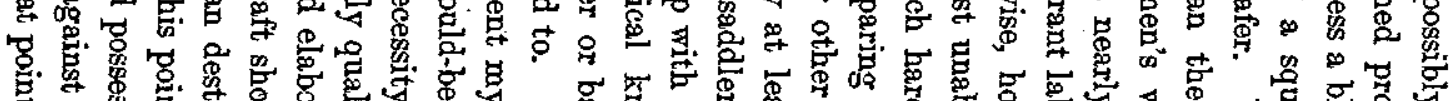

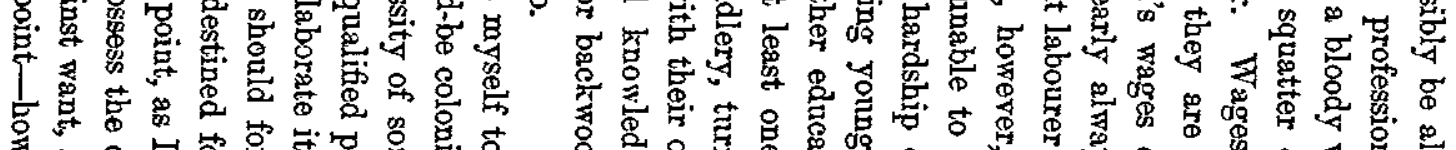

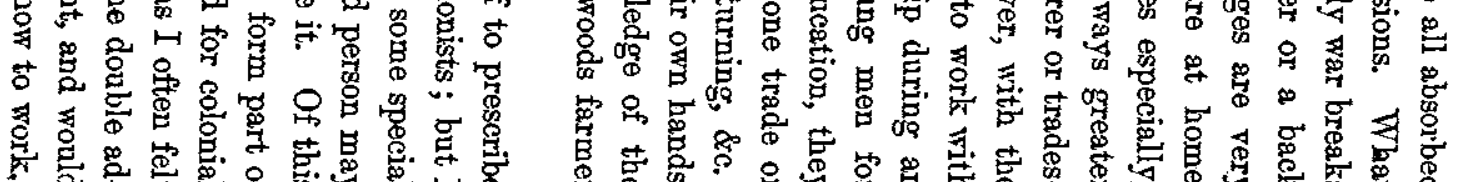

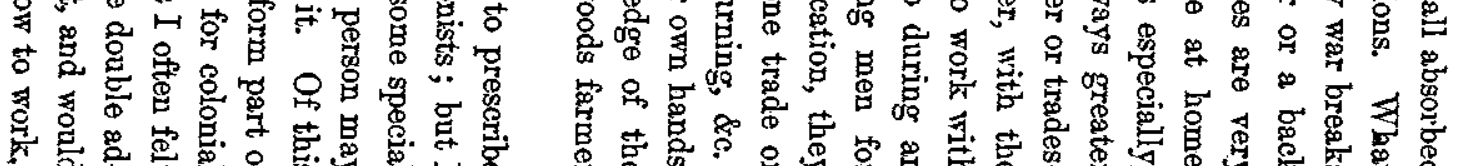

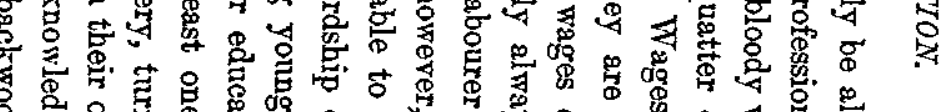

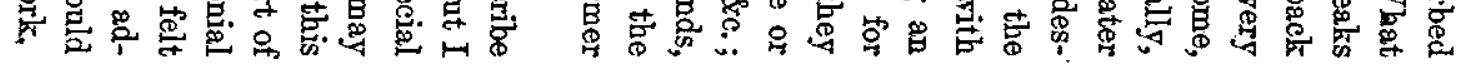

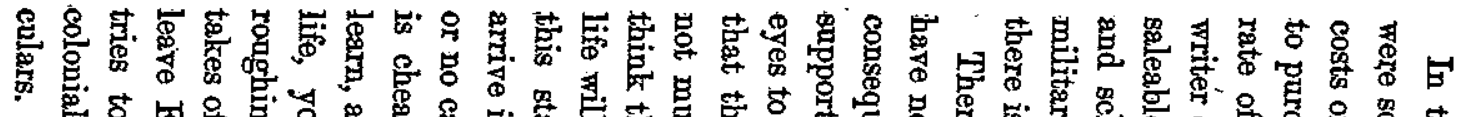

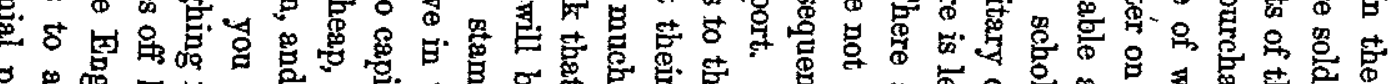

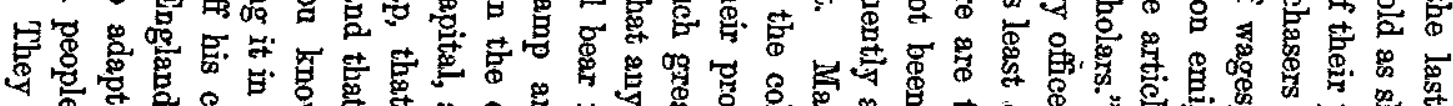

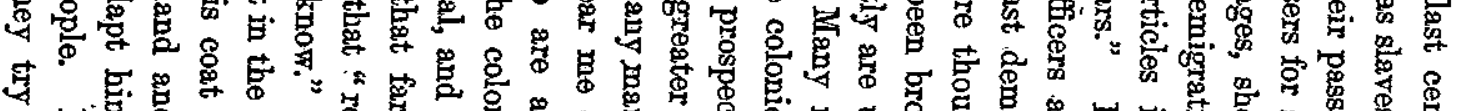

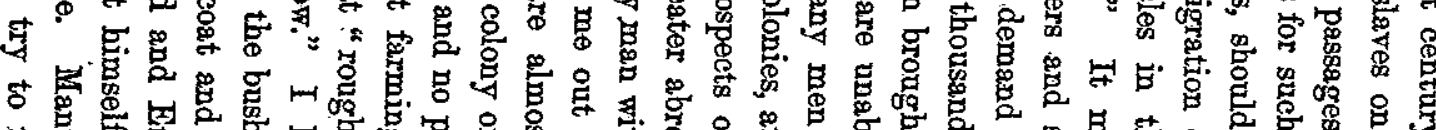

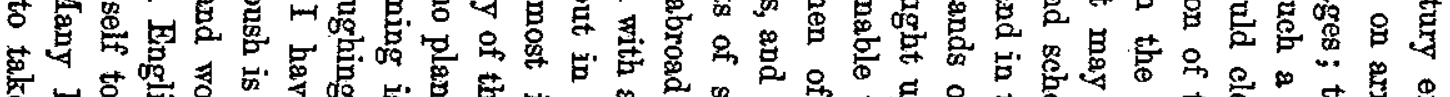

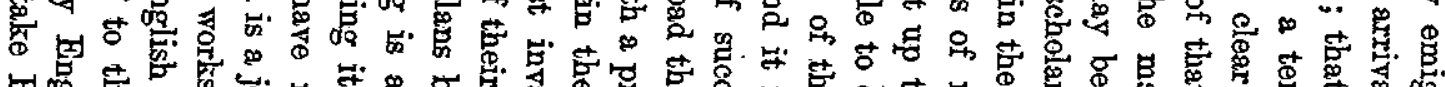

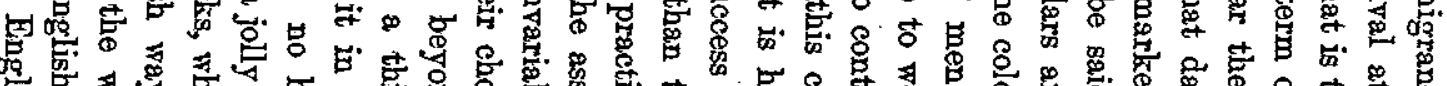

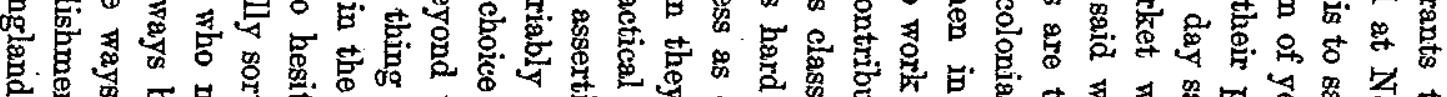

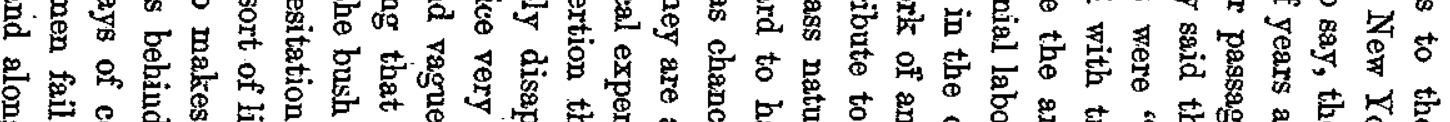

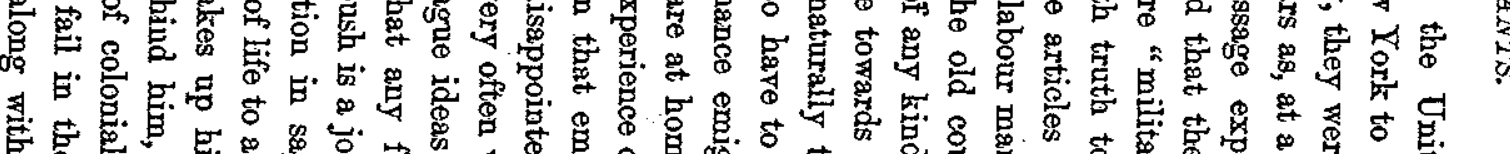

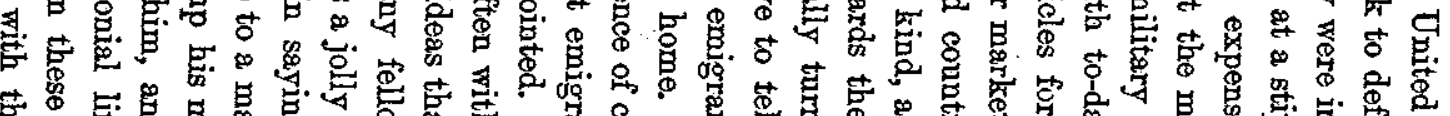

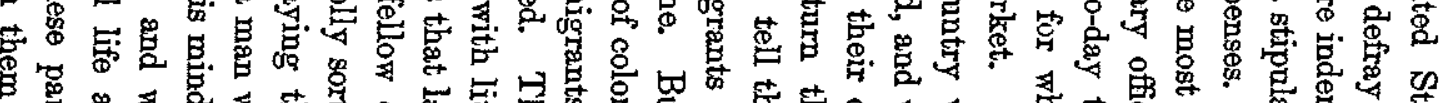

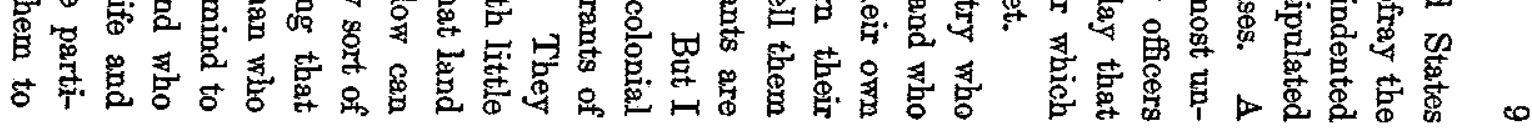




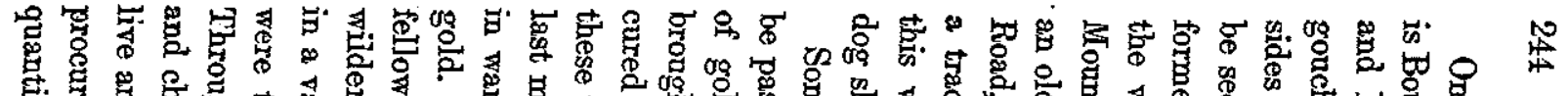

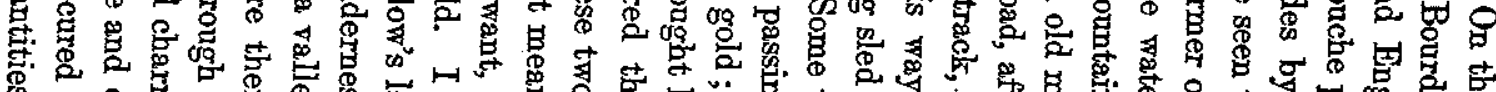

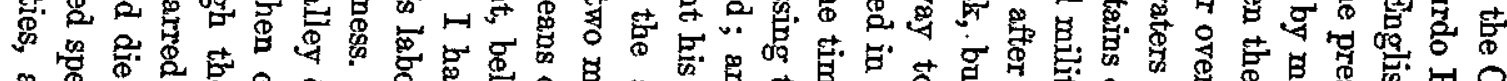

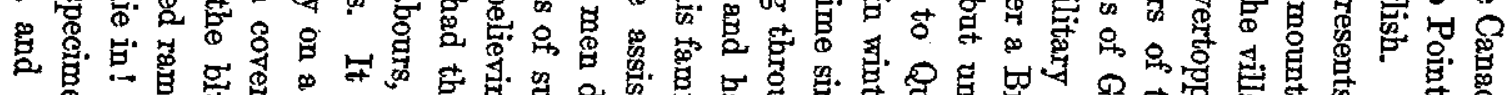

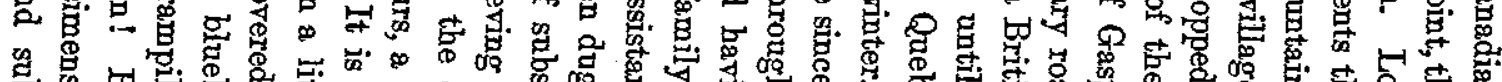

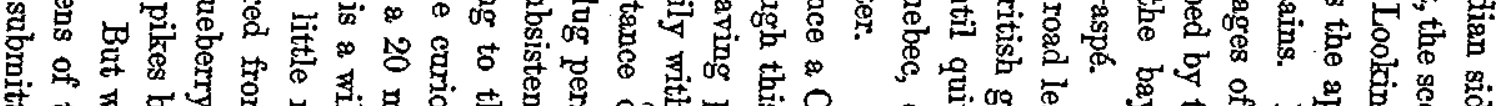

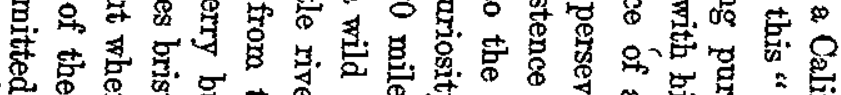

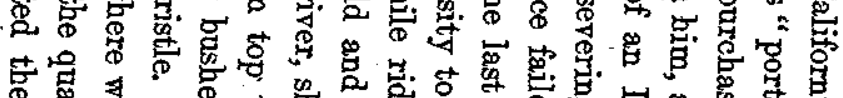

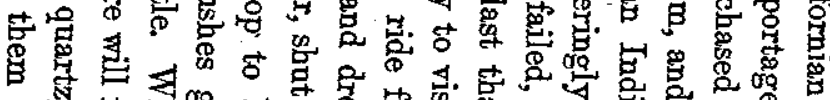

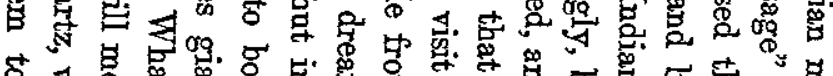

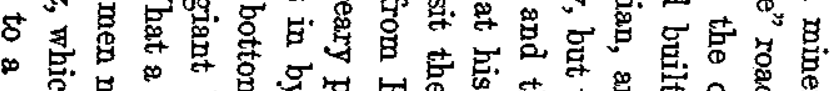

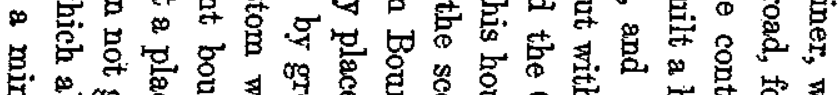

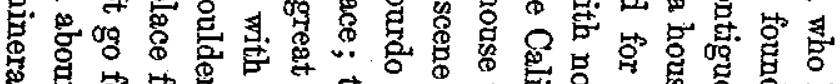

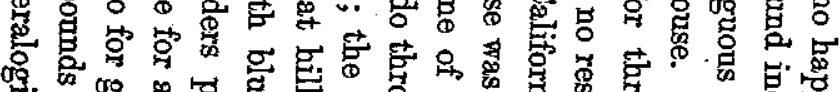

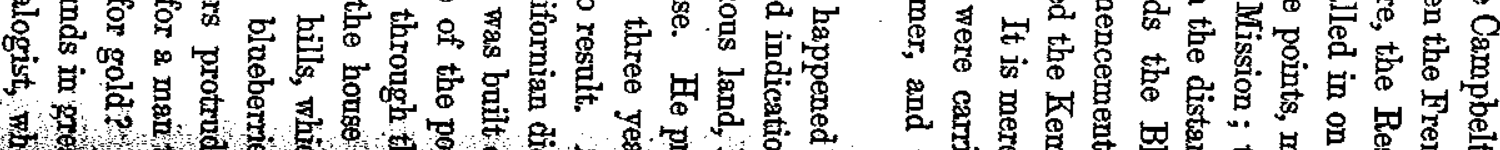

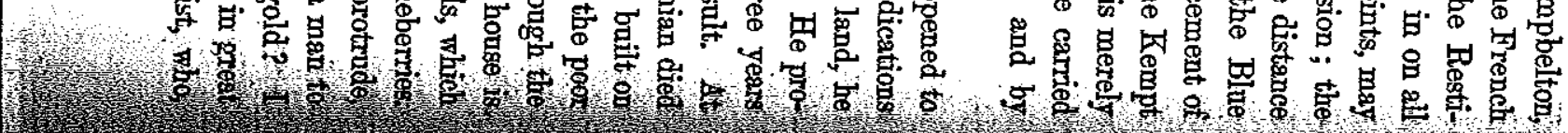

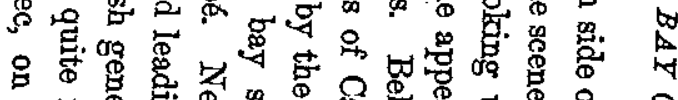

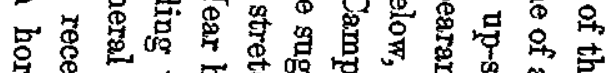

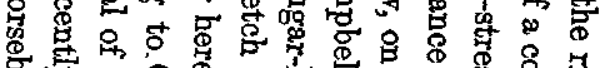

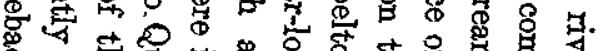

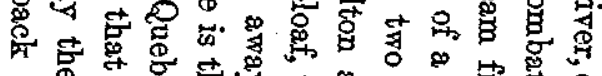

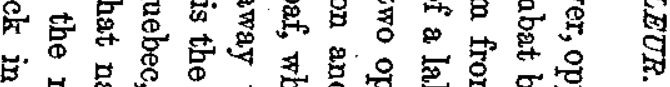

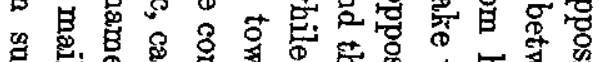

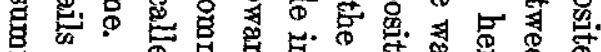

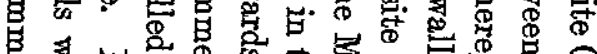

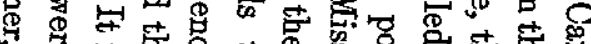

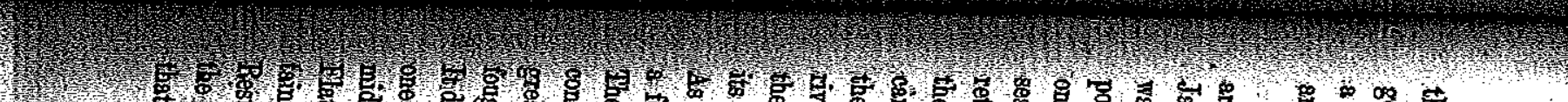

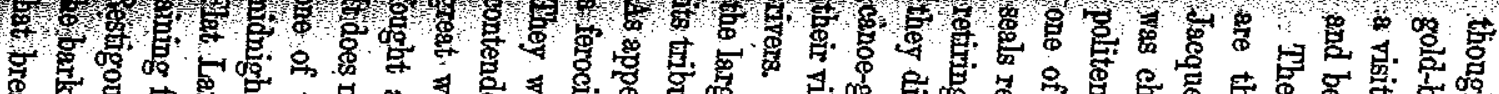

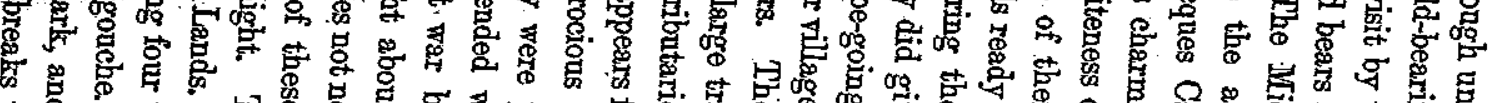

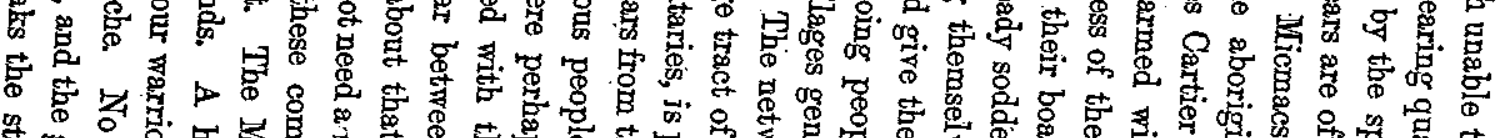

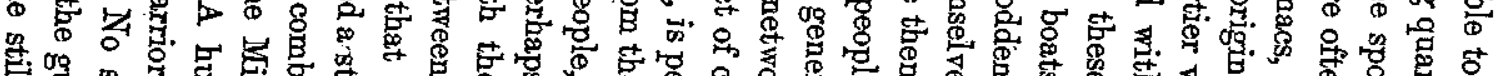

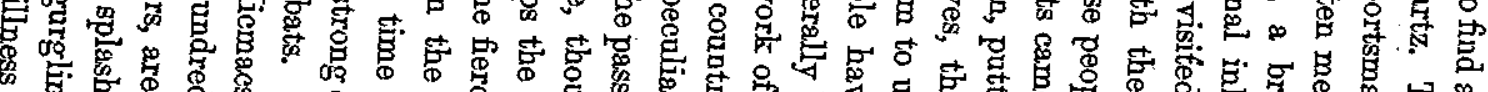

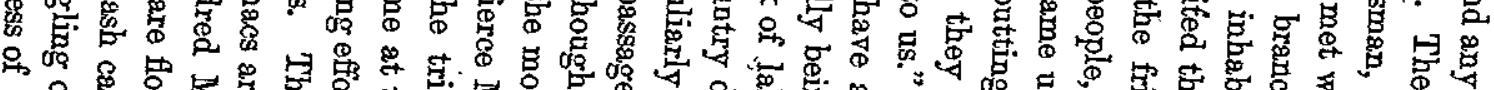

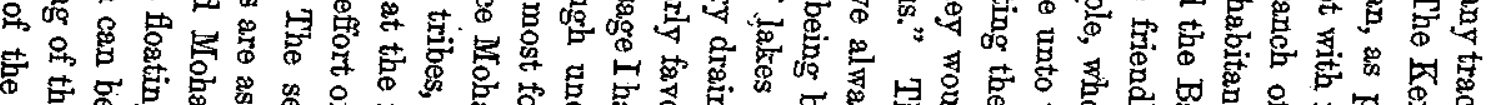

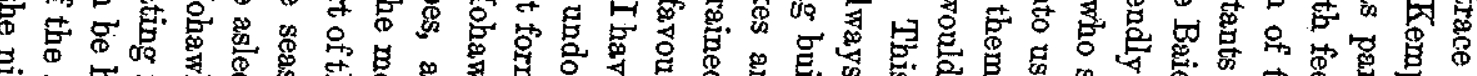

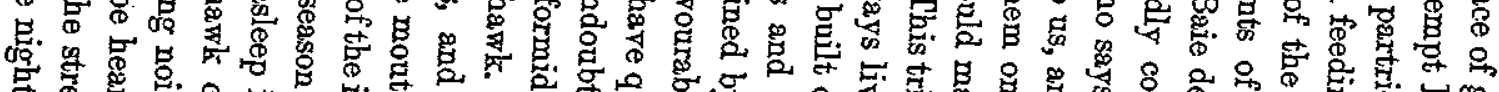

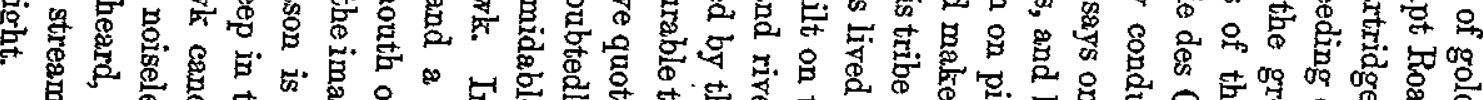

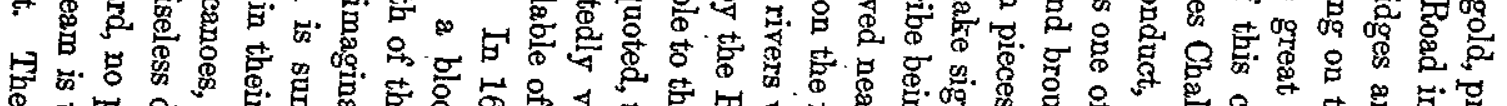

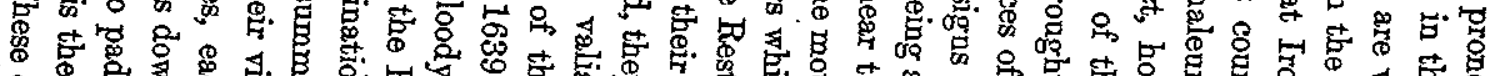

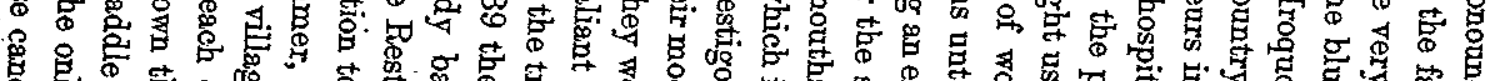

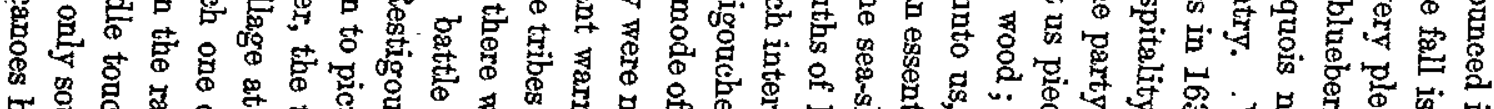

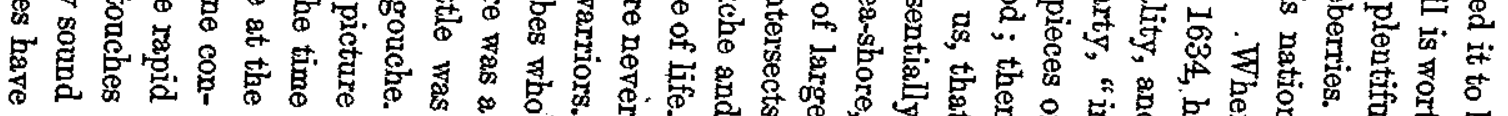




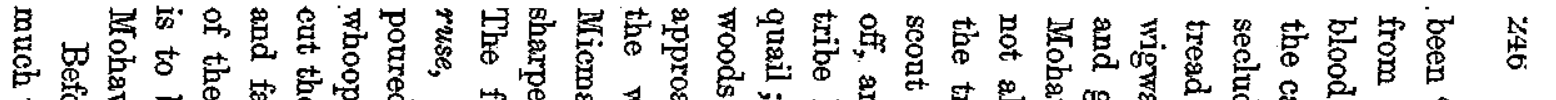

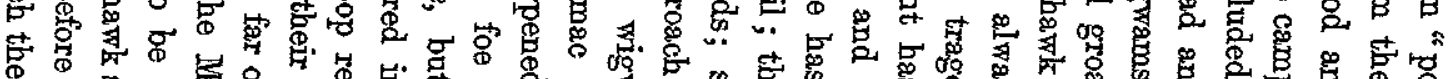

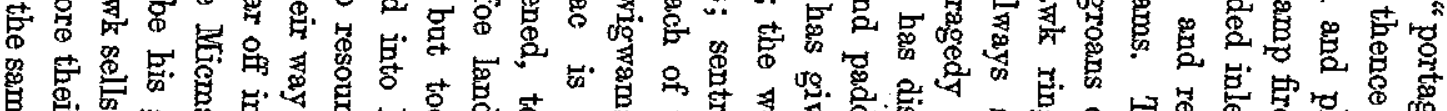

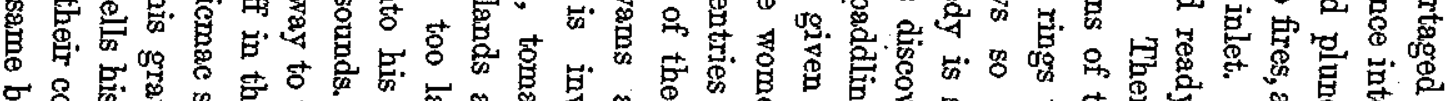

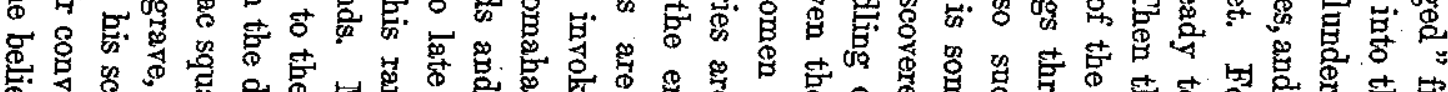

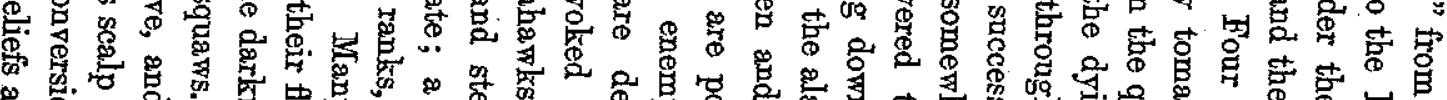

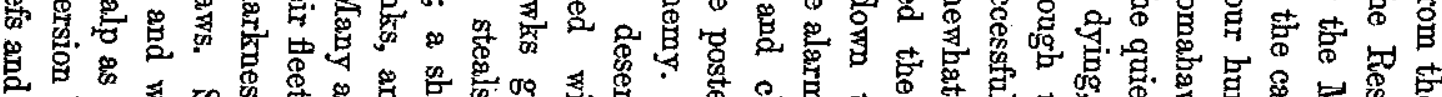

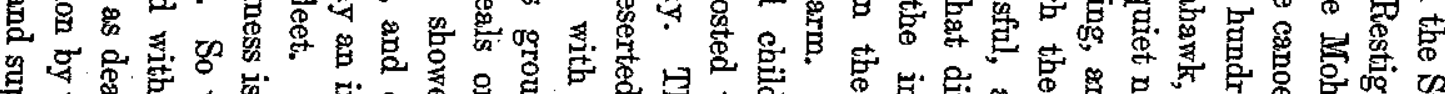

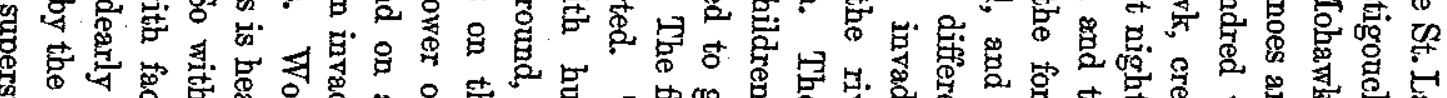

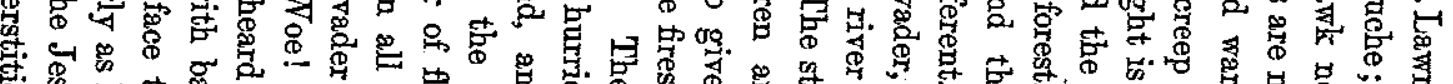

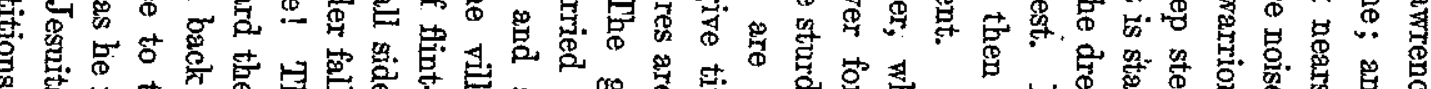

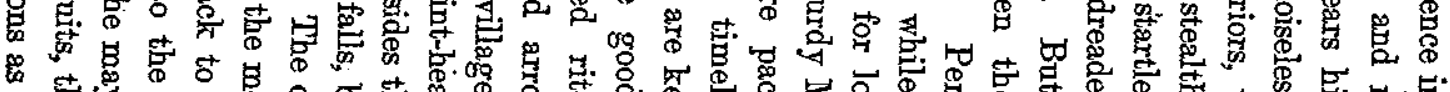

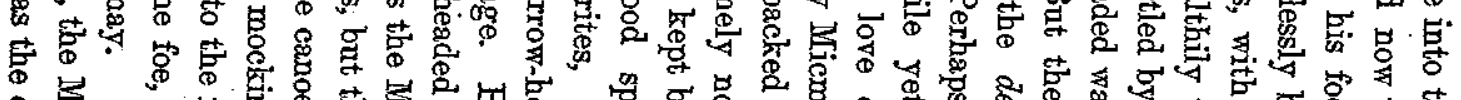

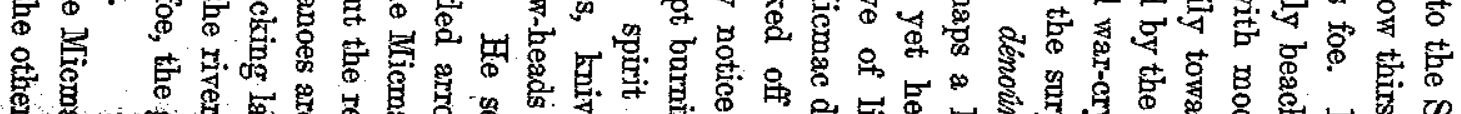

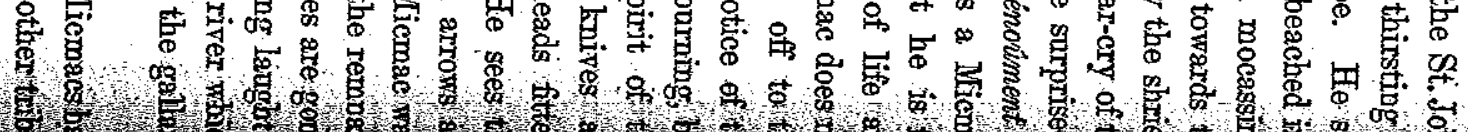

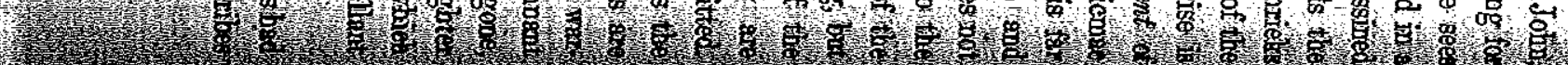

6.

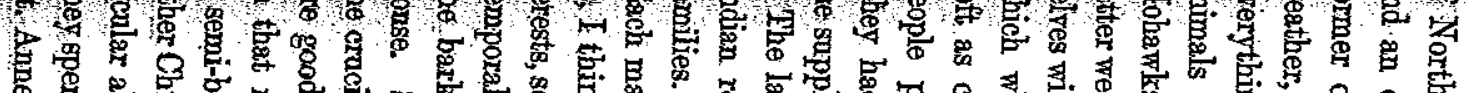

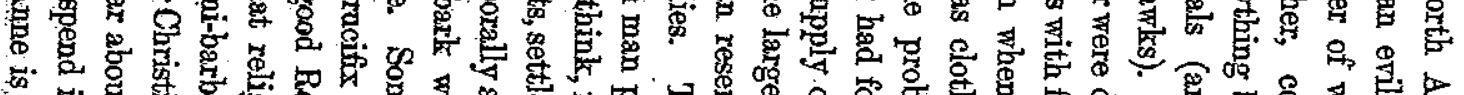

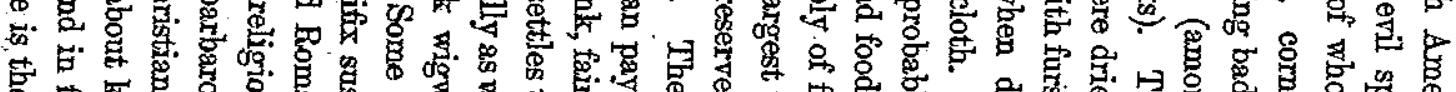

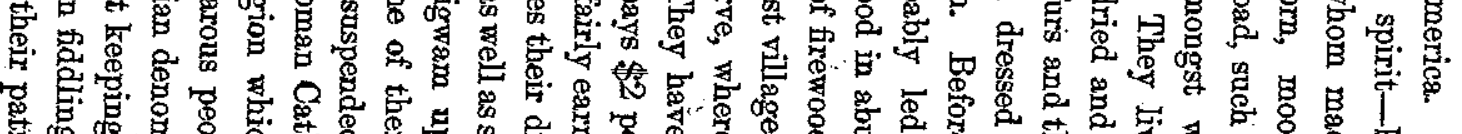

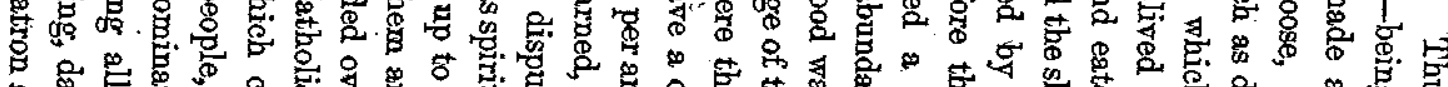

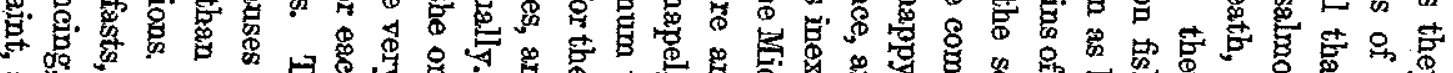

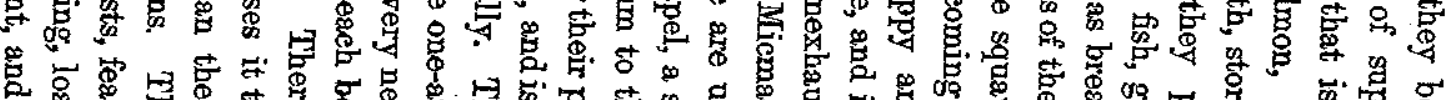

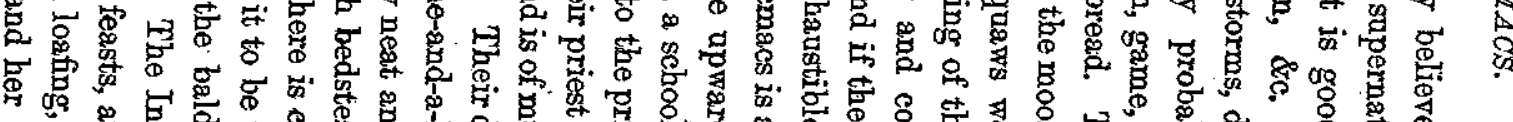

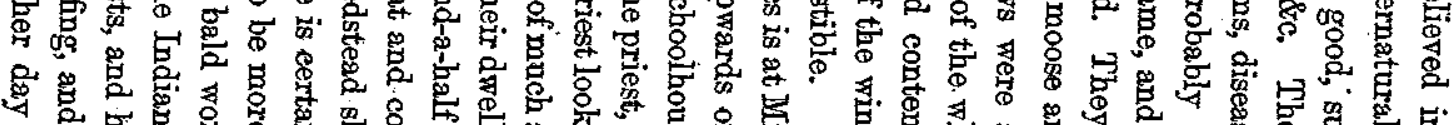

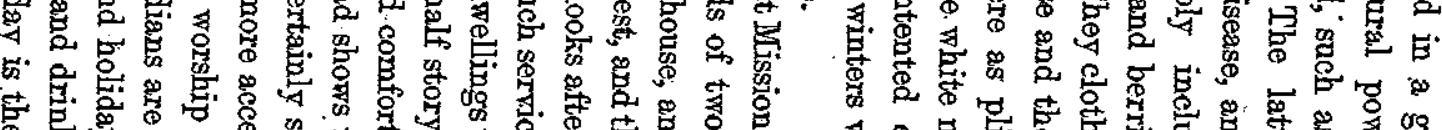

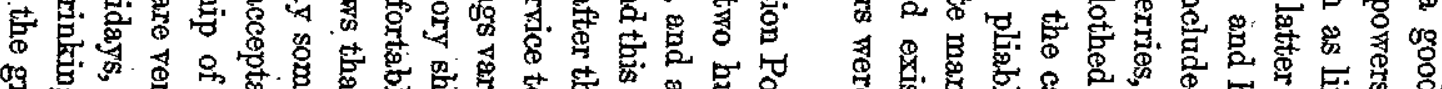

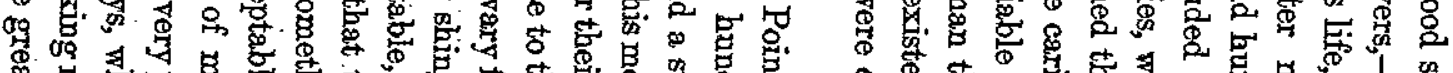

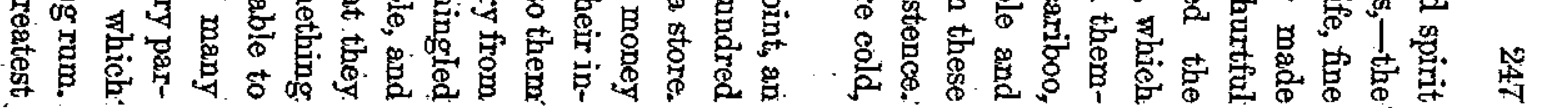




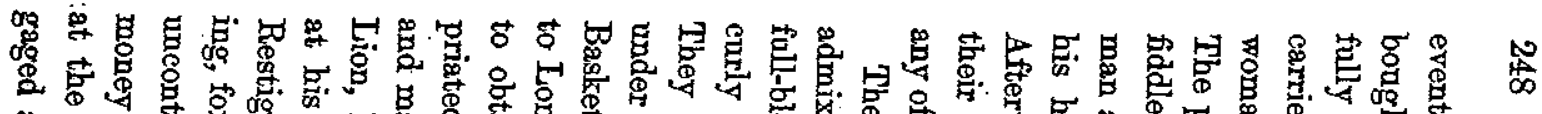

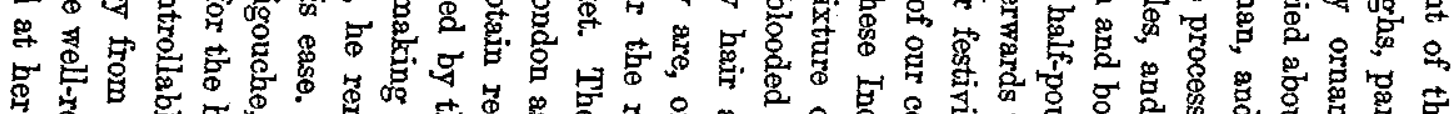

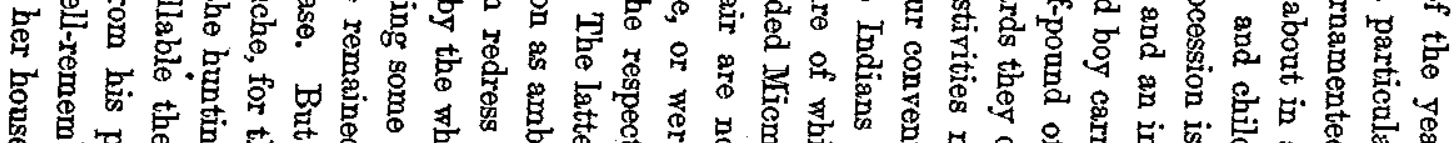

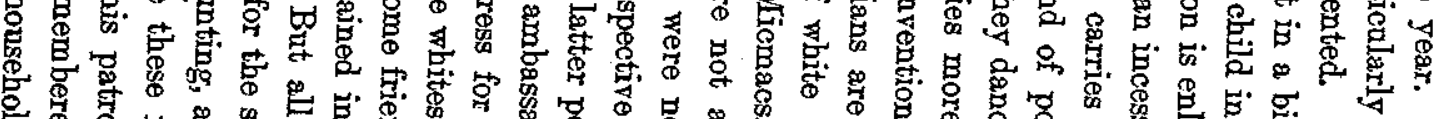

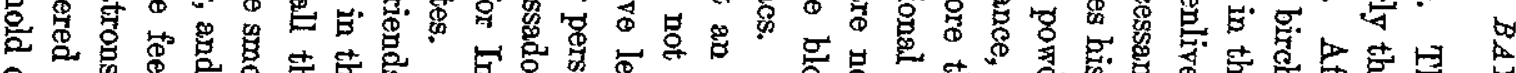

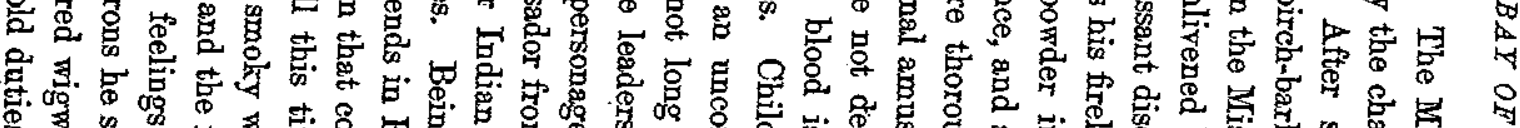

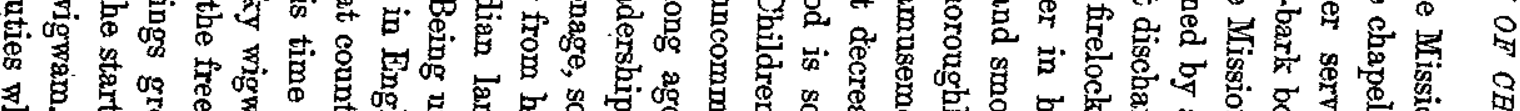

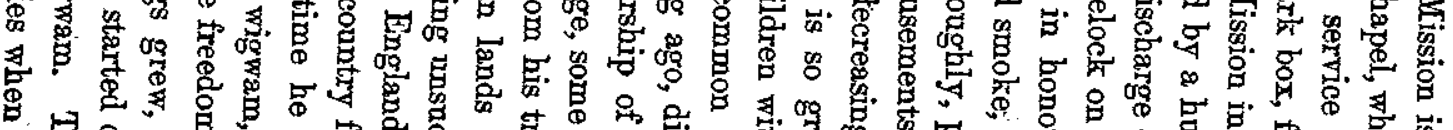

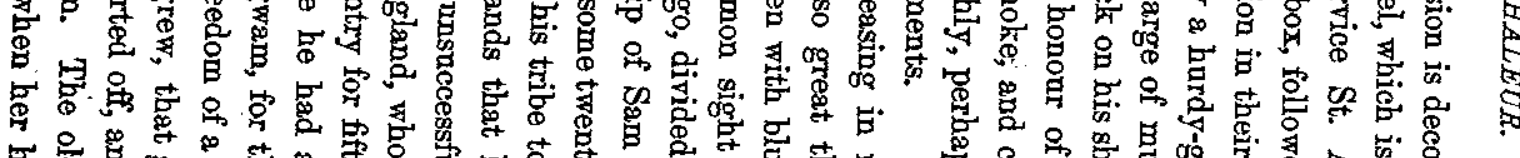

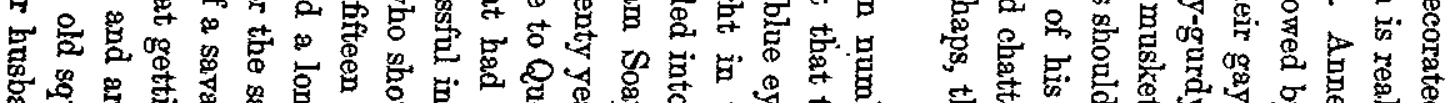

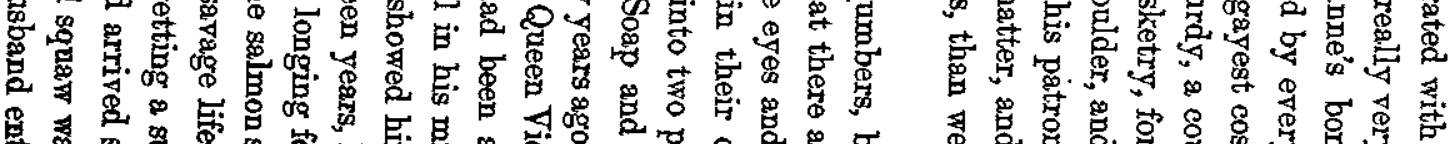

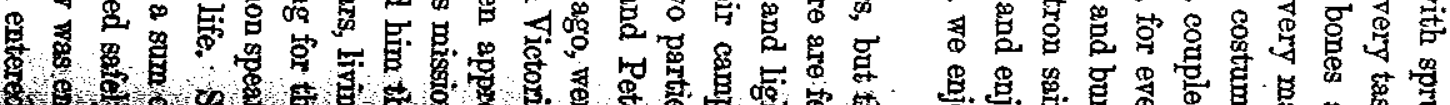

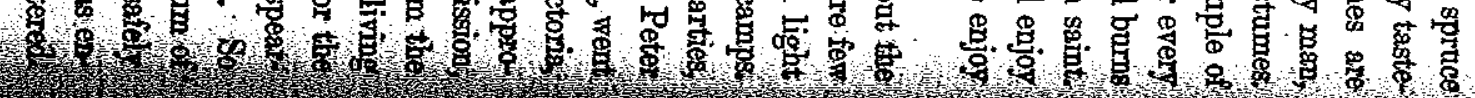

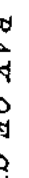
舟

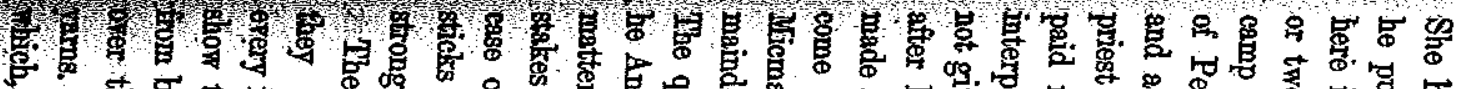

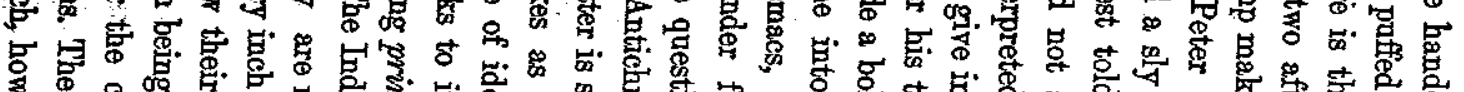

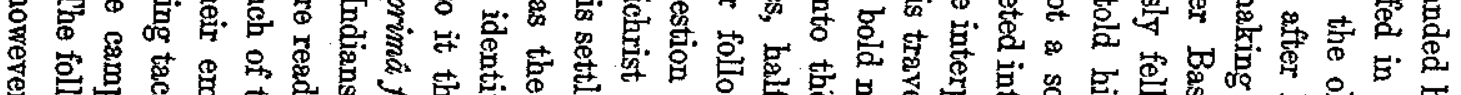

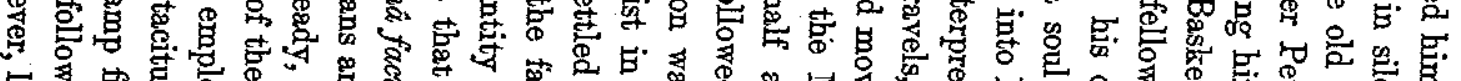

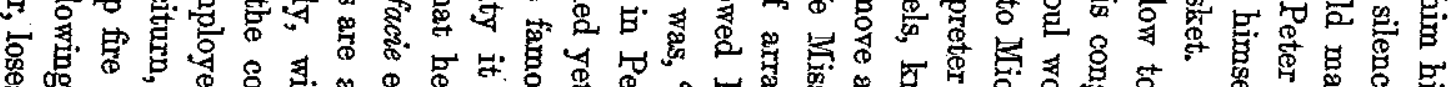

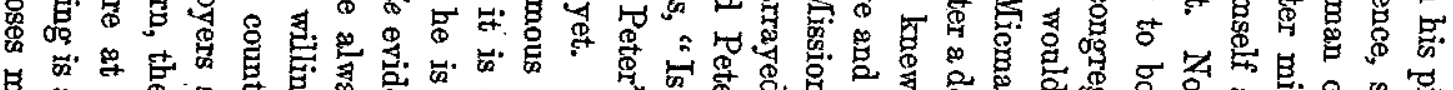

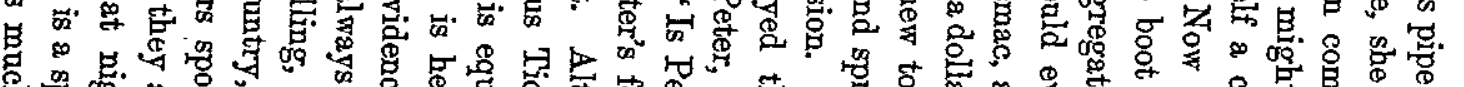

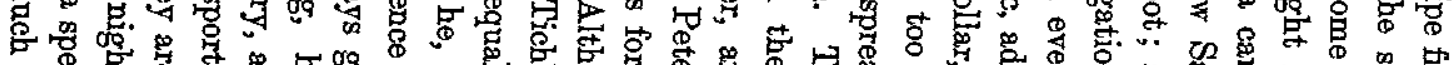

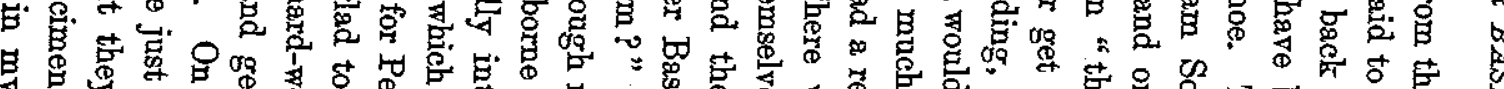

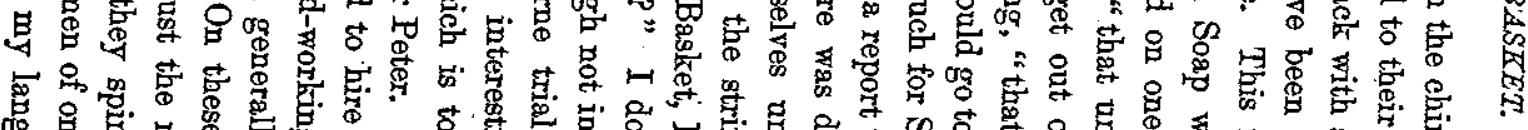

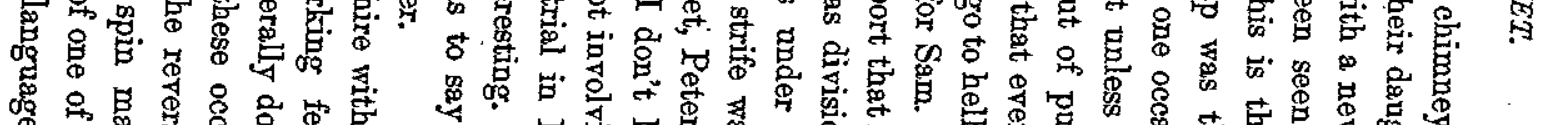

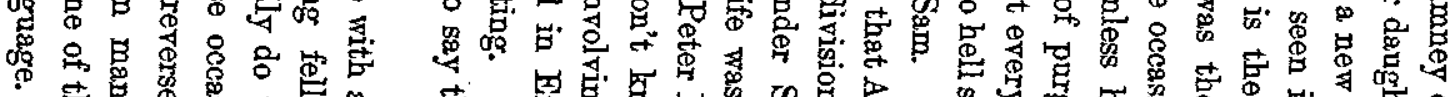

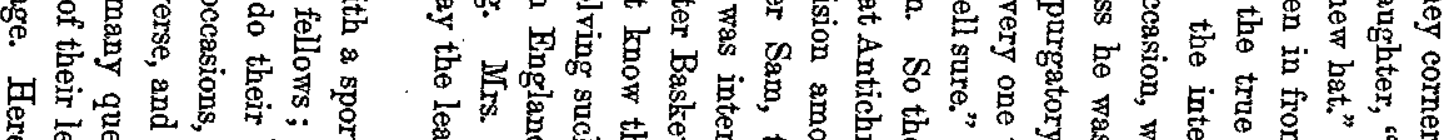

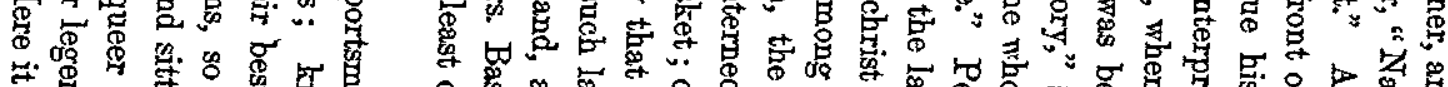

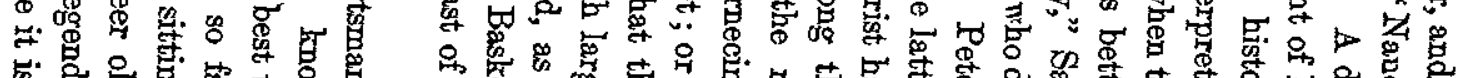

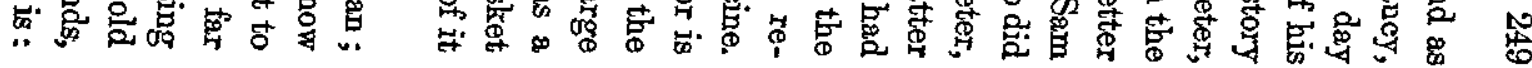




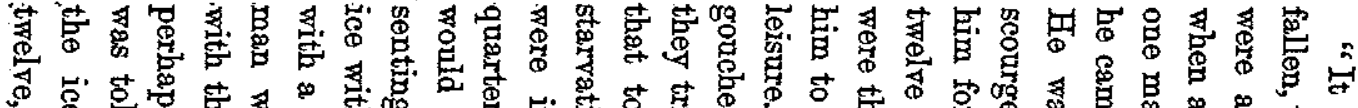

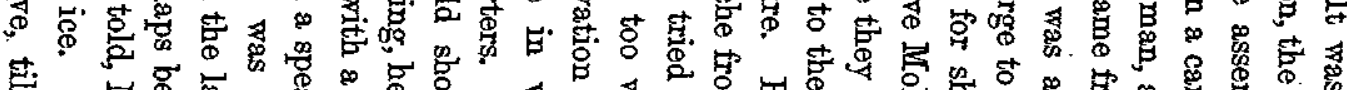

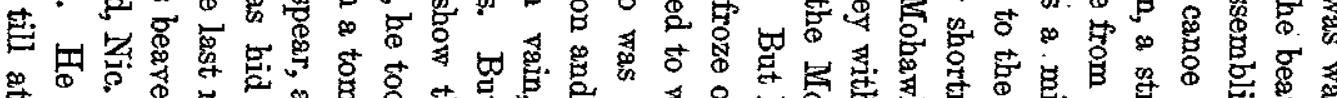

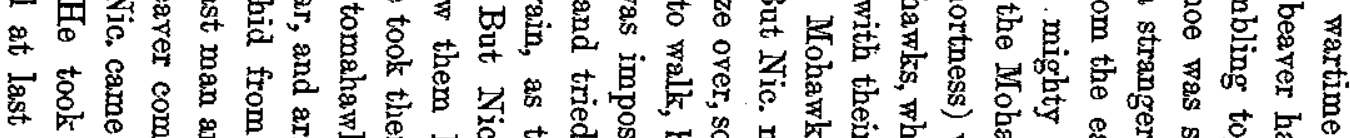

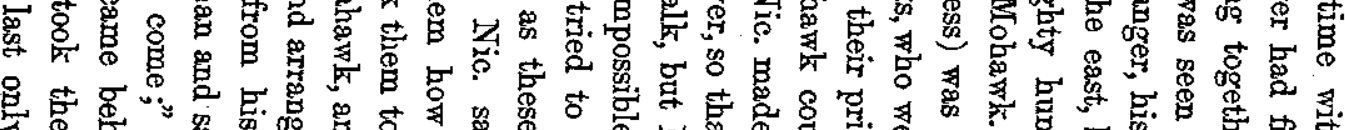

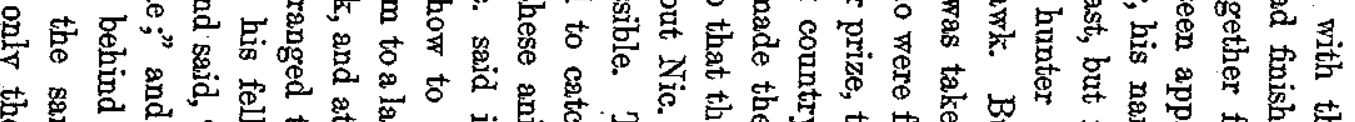

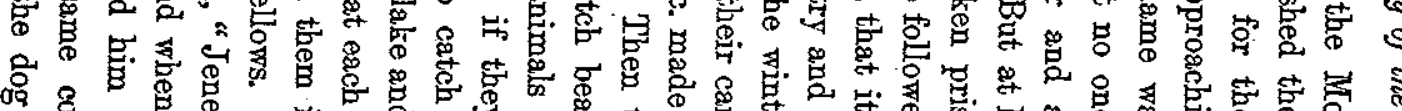

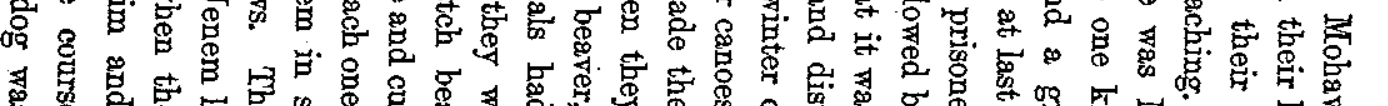

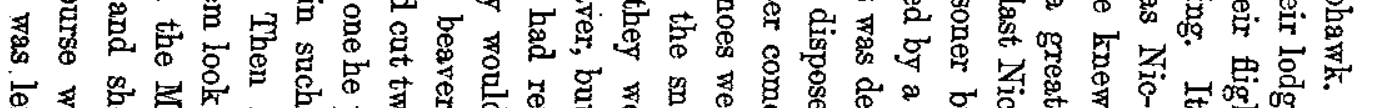

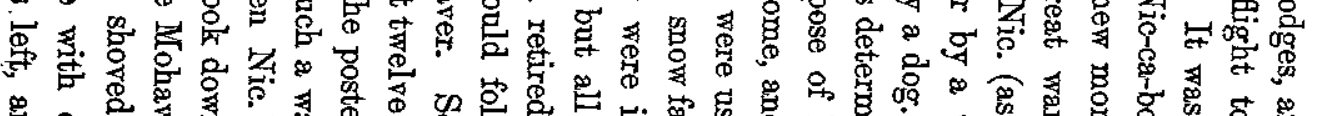

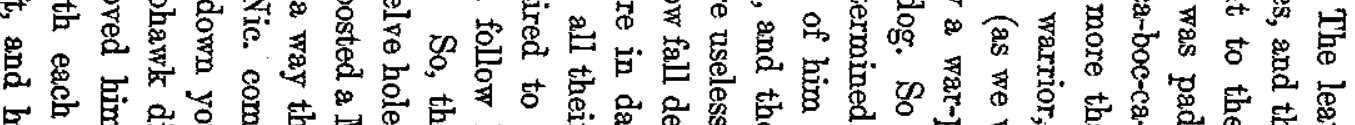

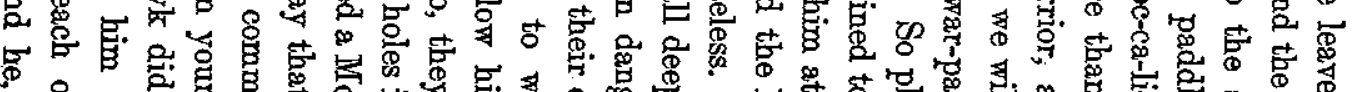

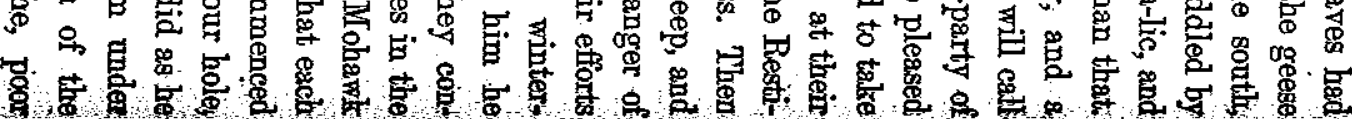

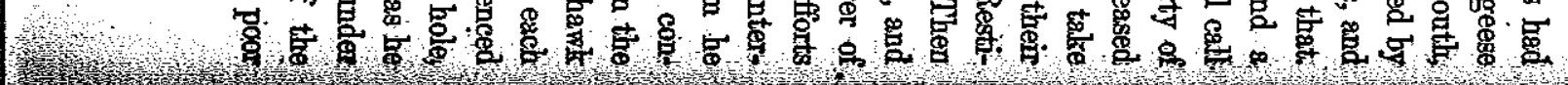

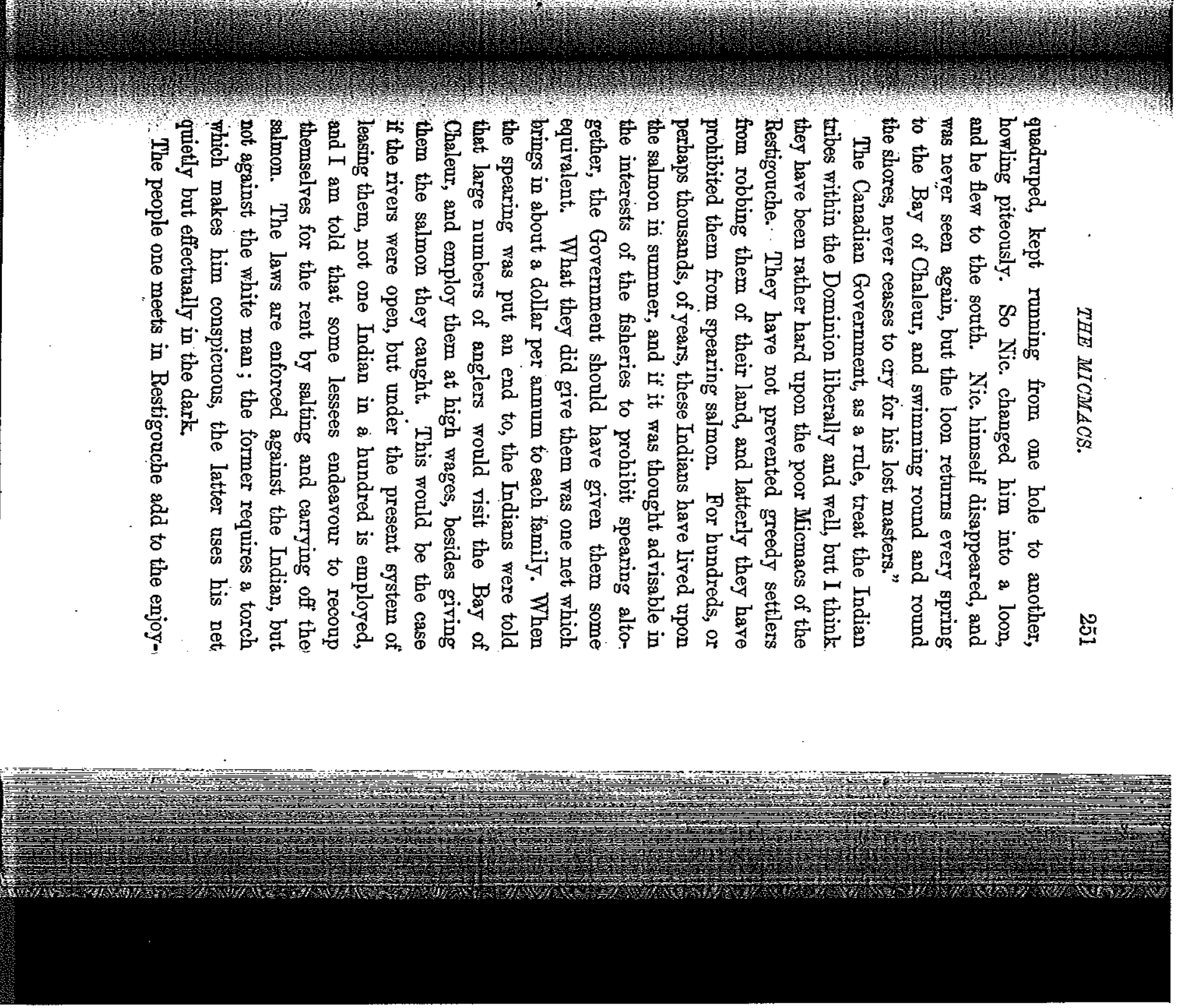




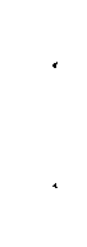




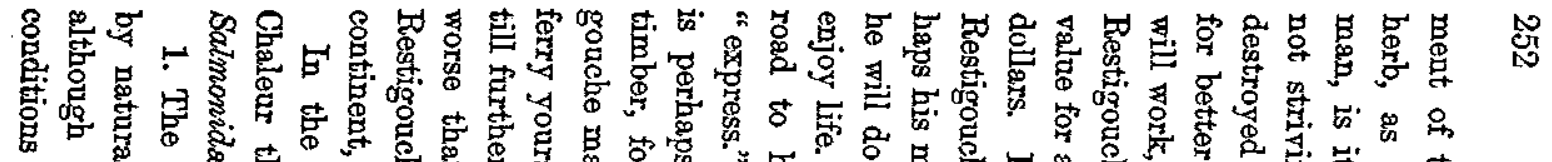

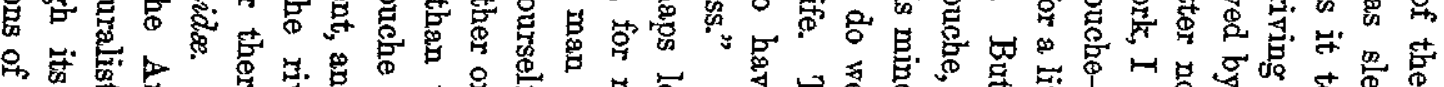

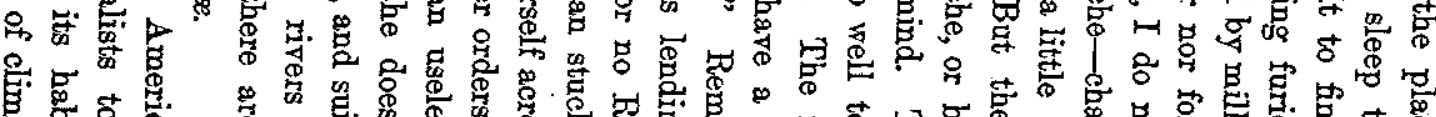

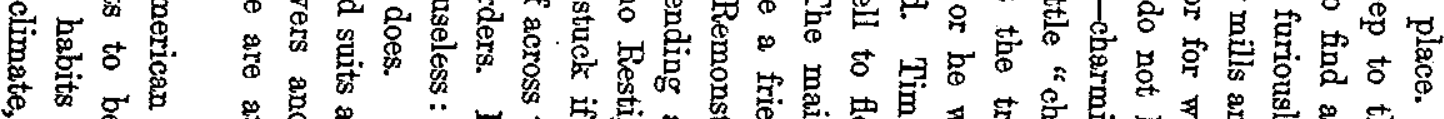

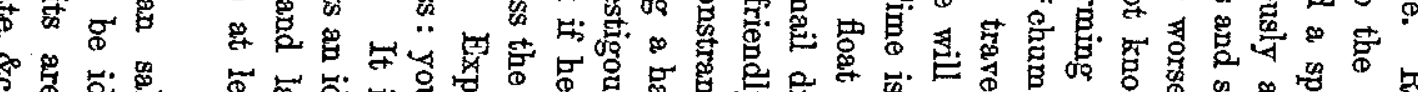

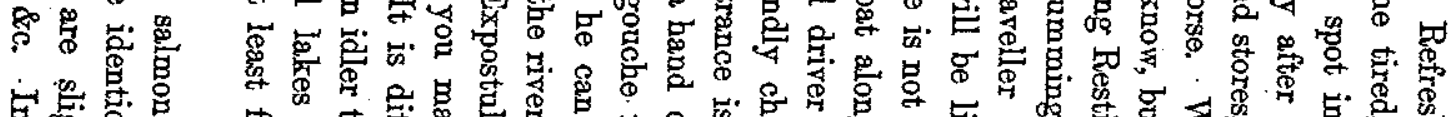

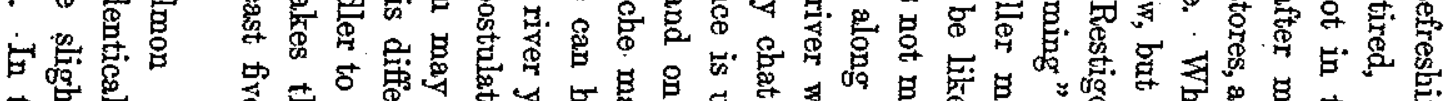

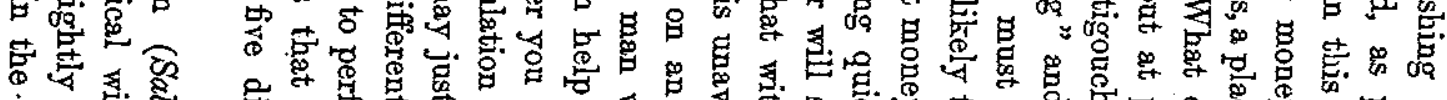

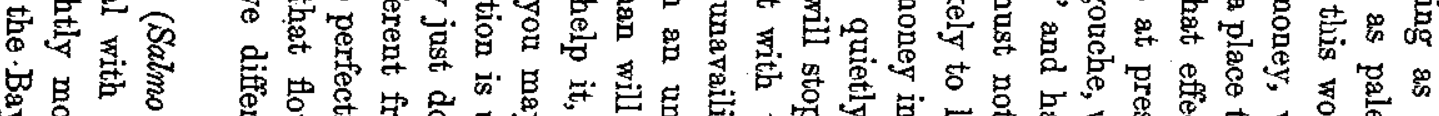

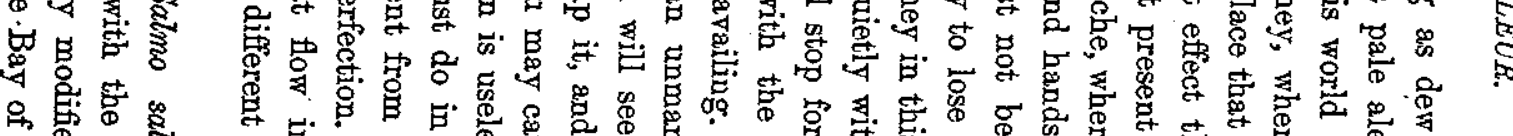

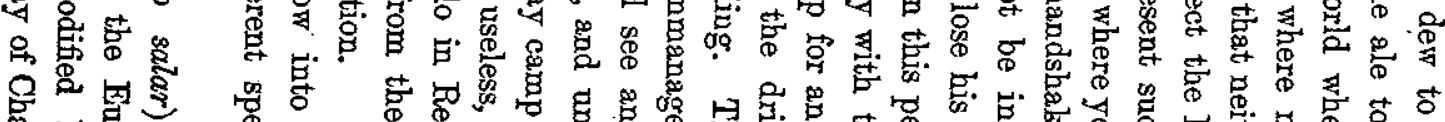

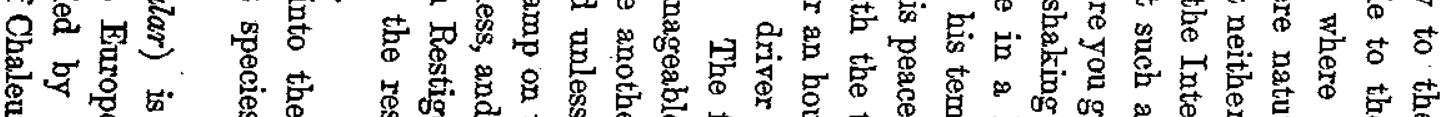

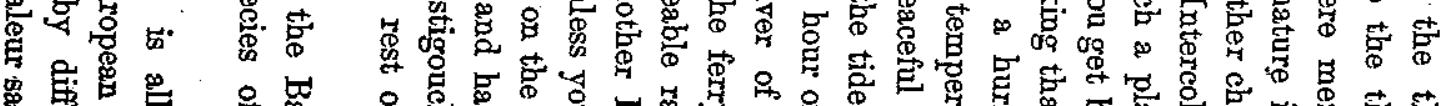

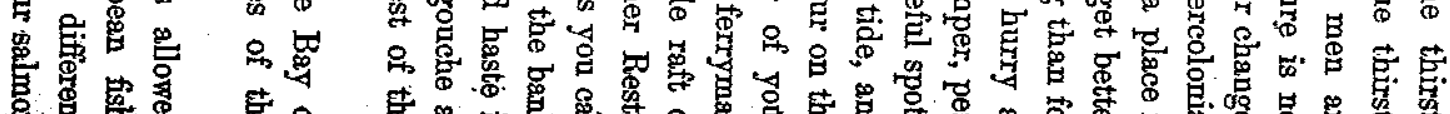

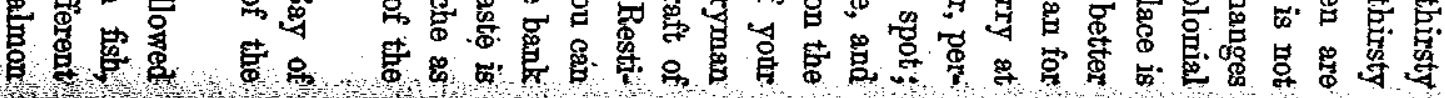




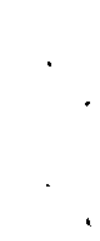




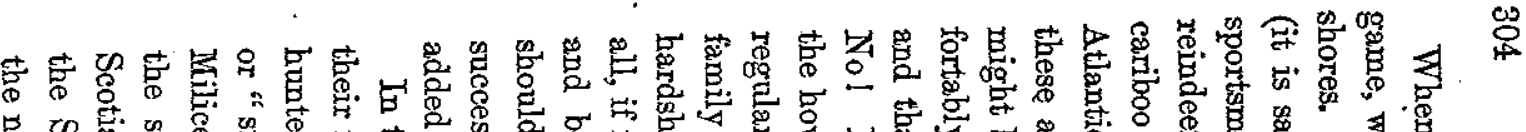

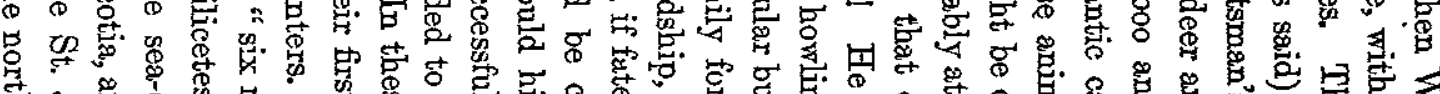

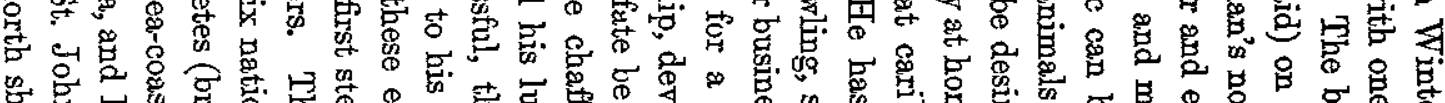

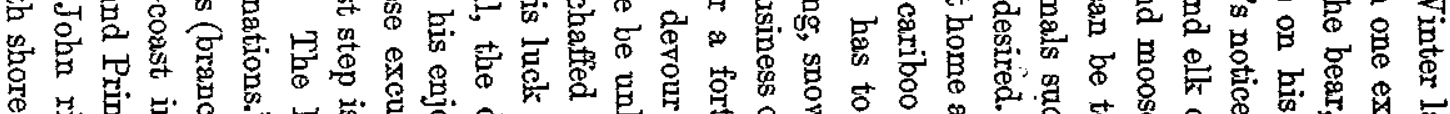

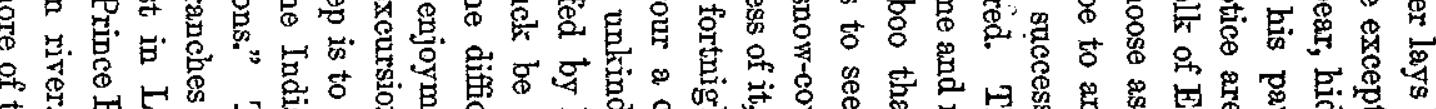

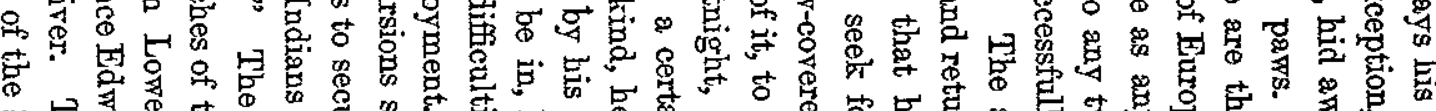

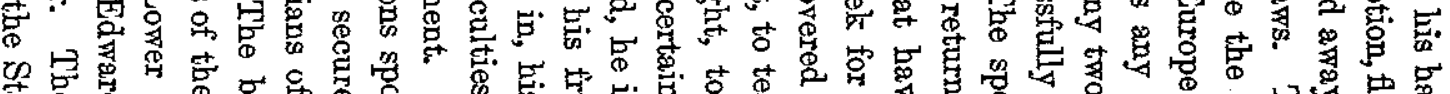

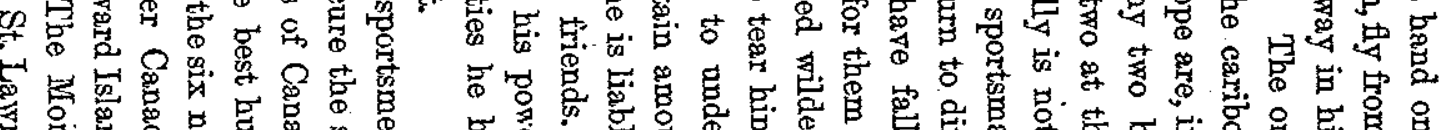

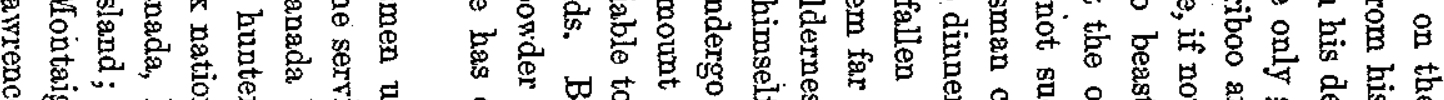

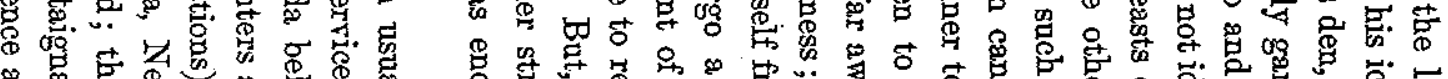

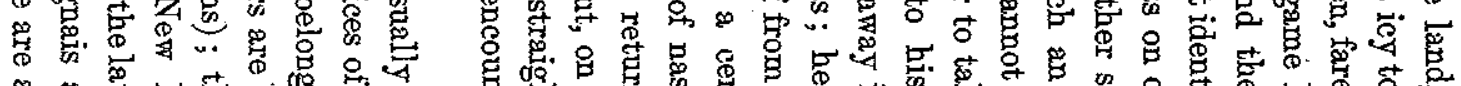

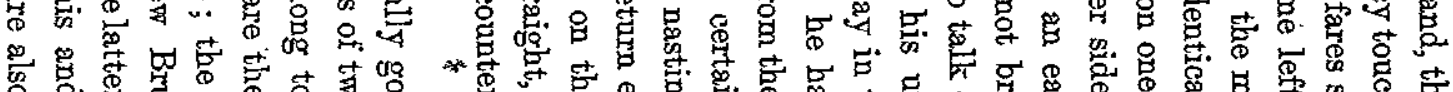

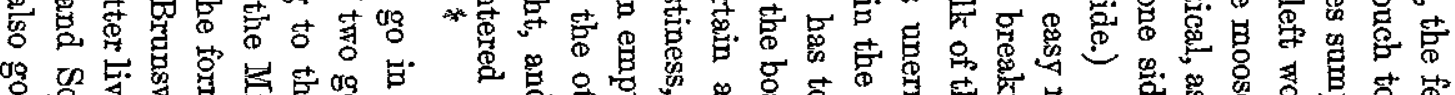

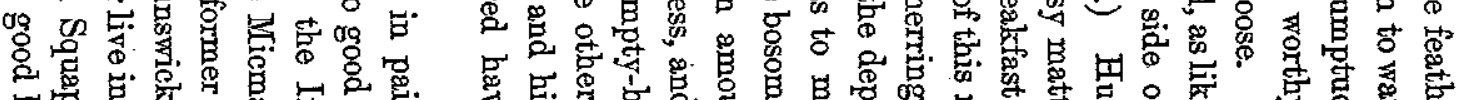

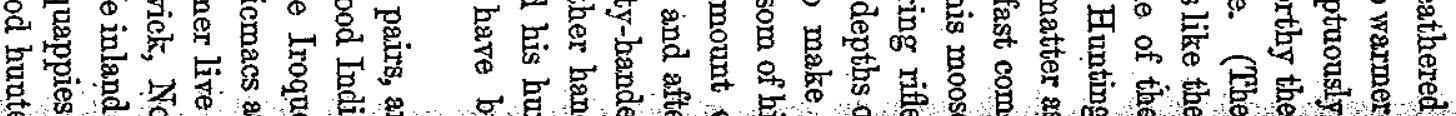

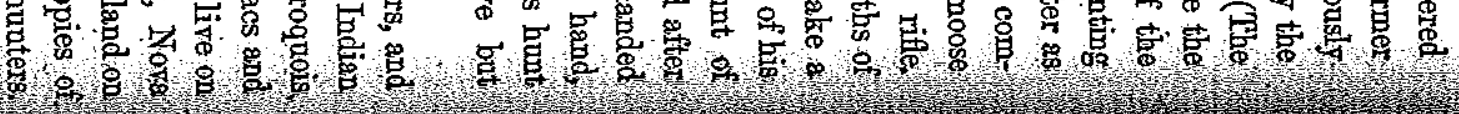

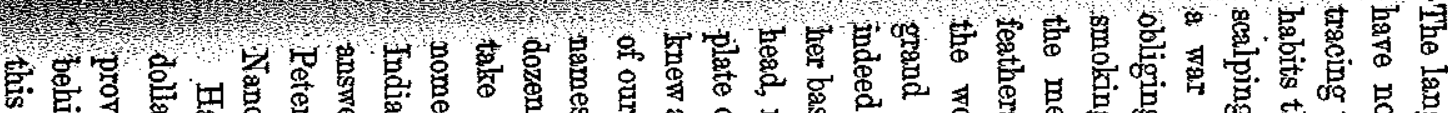

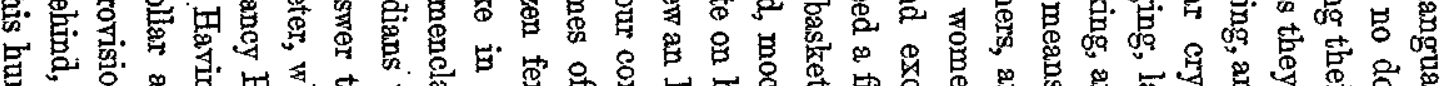

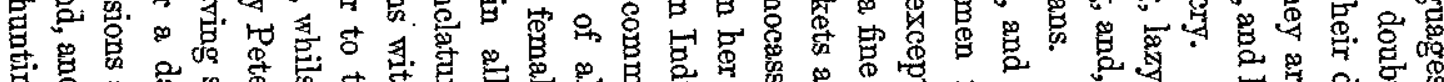

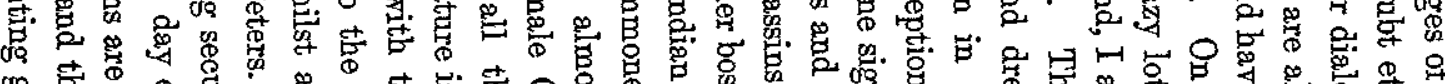

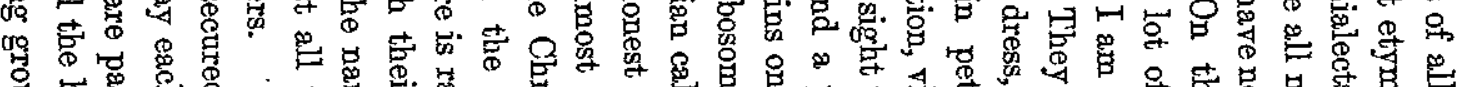

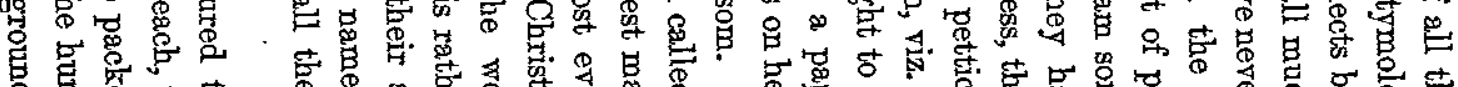

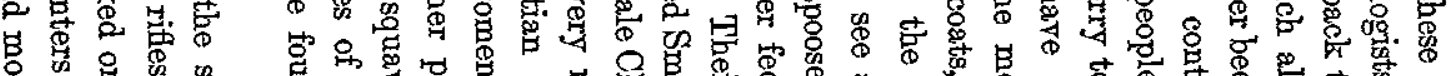

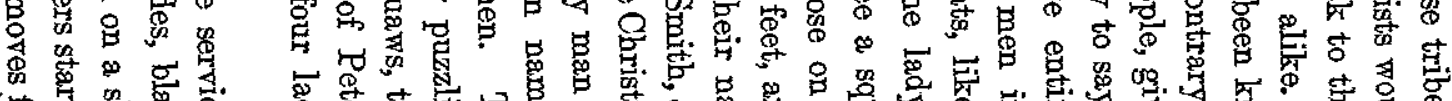

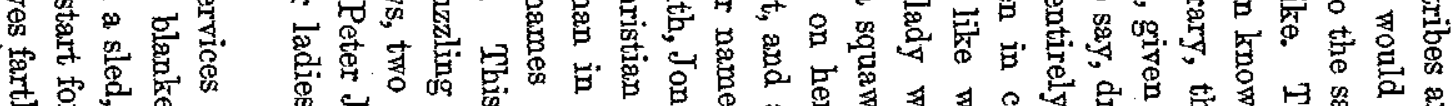

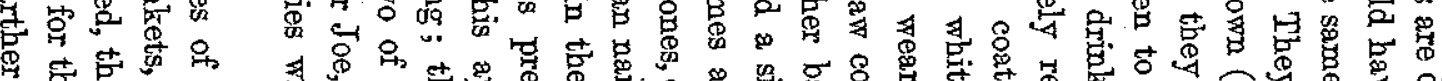

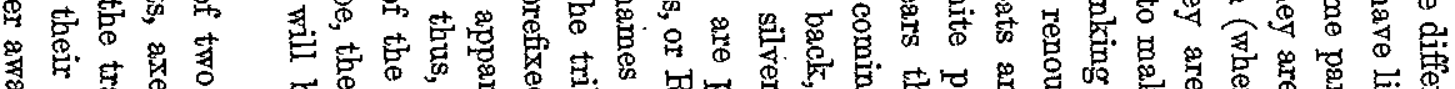

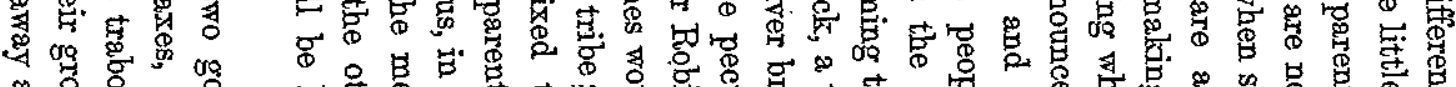

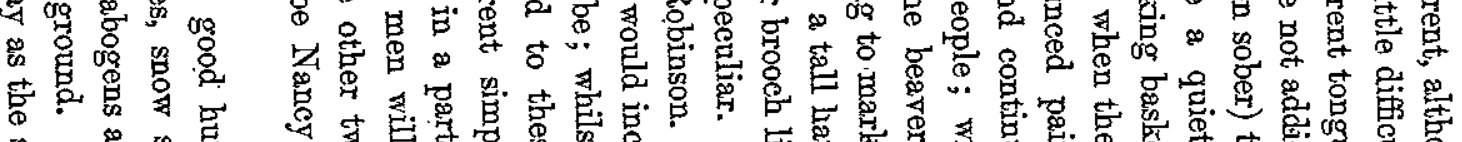

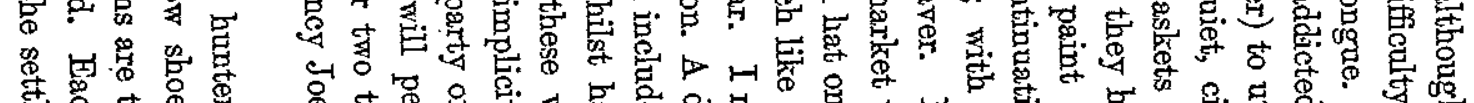

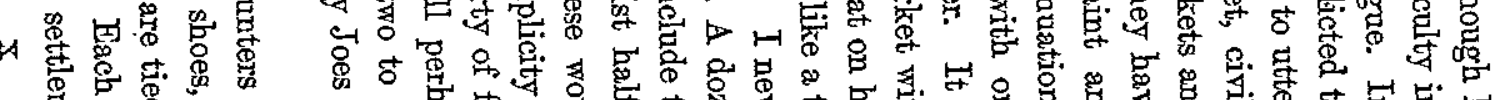

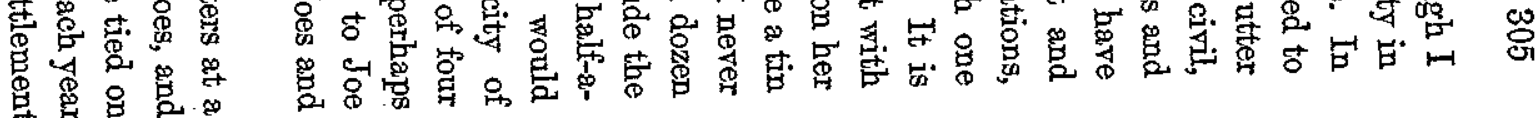




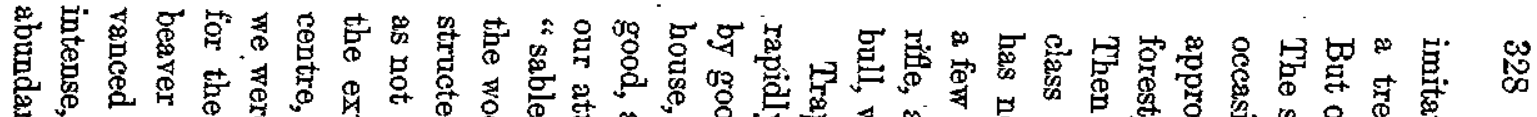

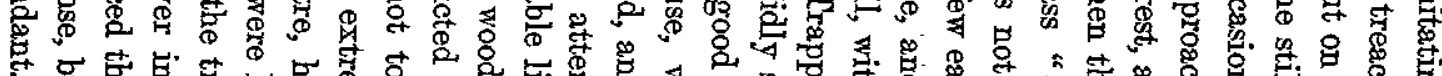

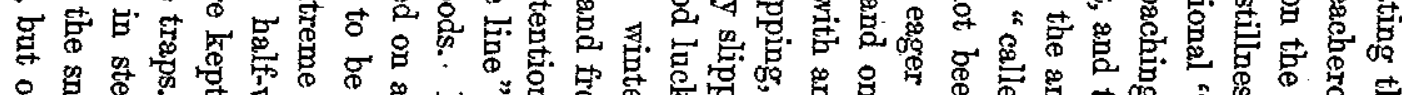

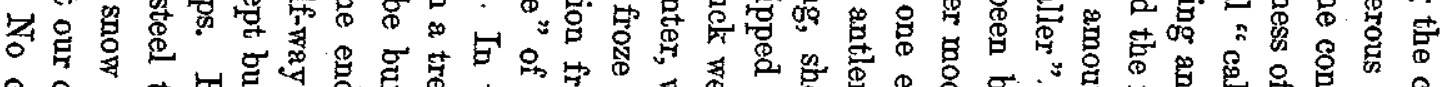

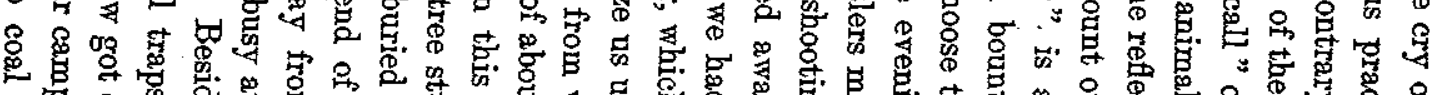

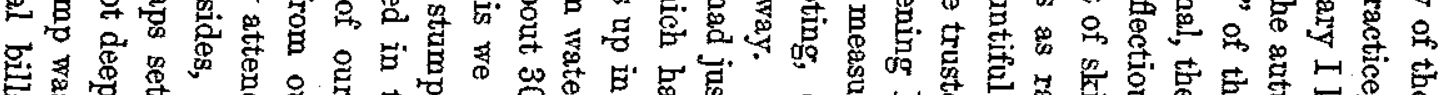

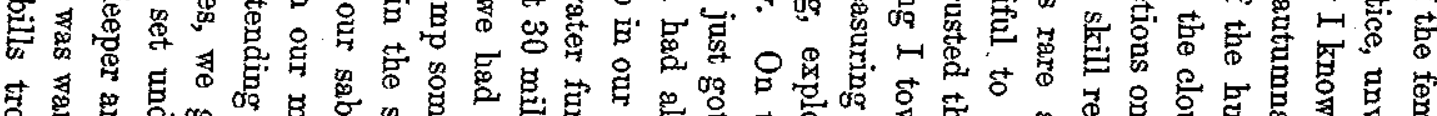

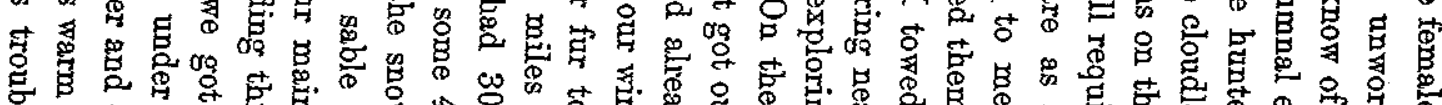

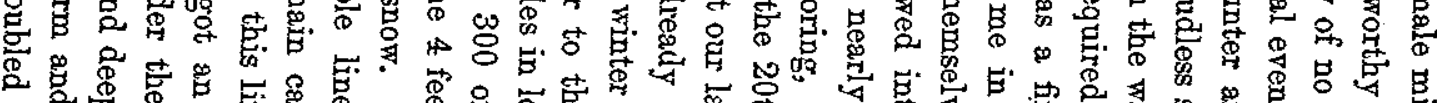

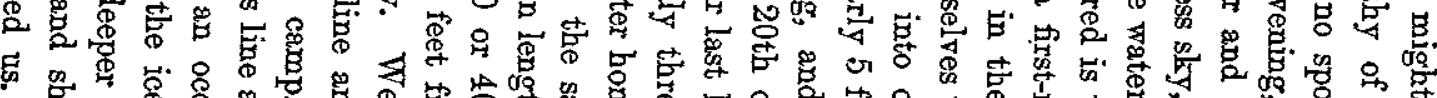

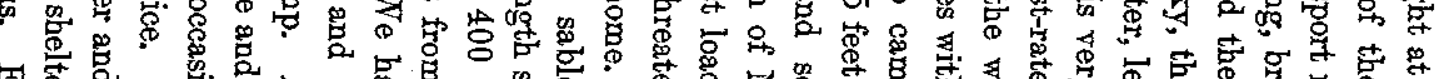

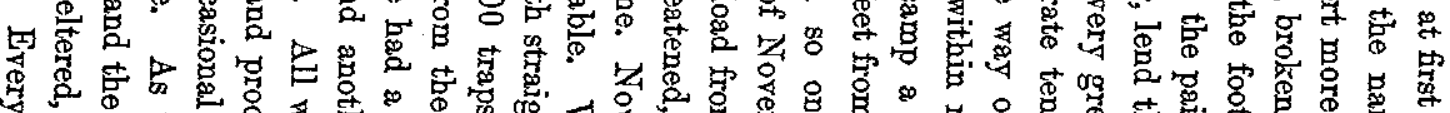

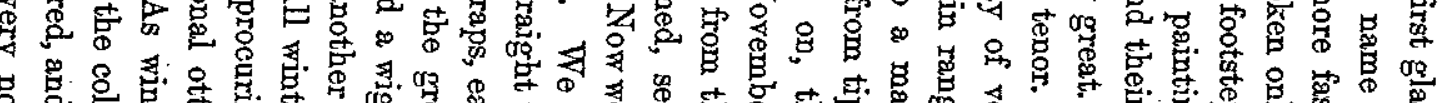

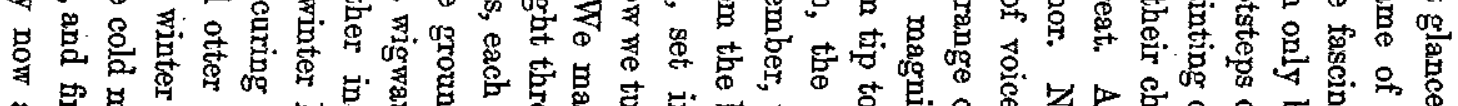

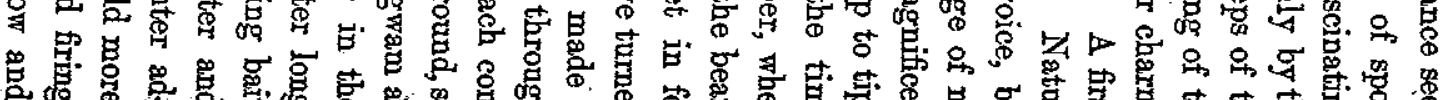

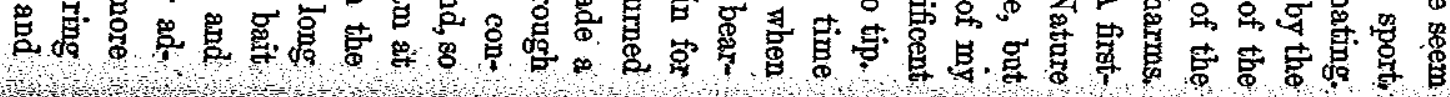

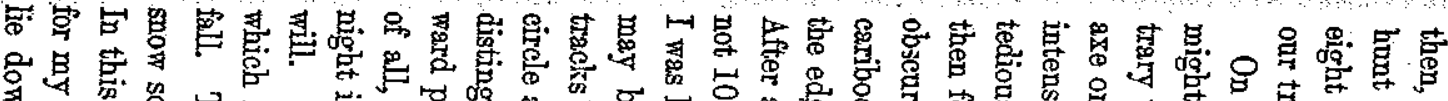

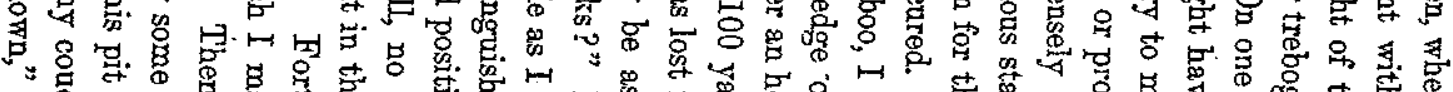

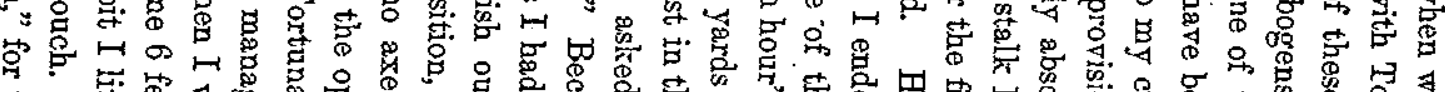

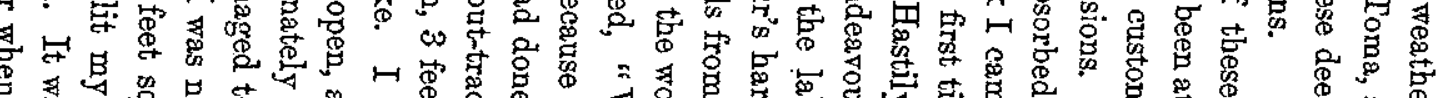

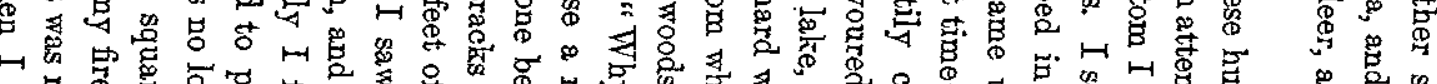

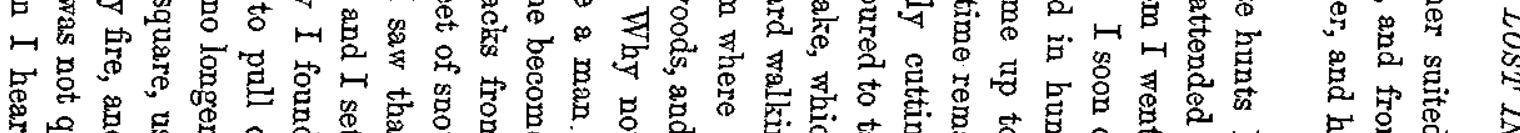

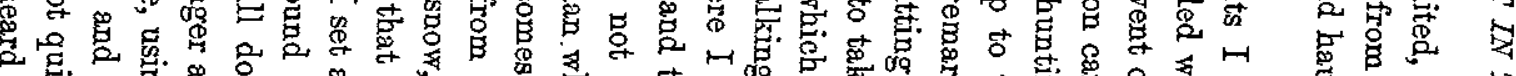

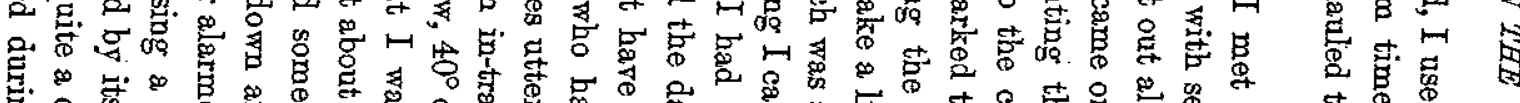

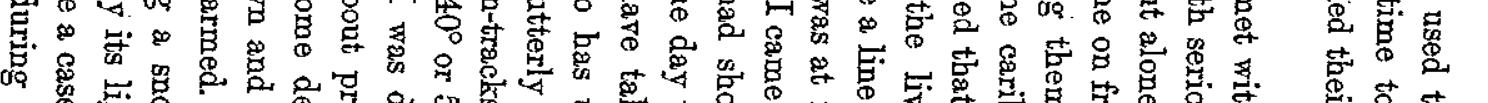

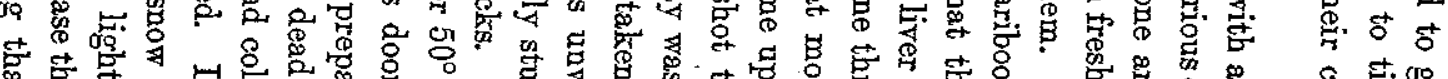

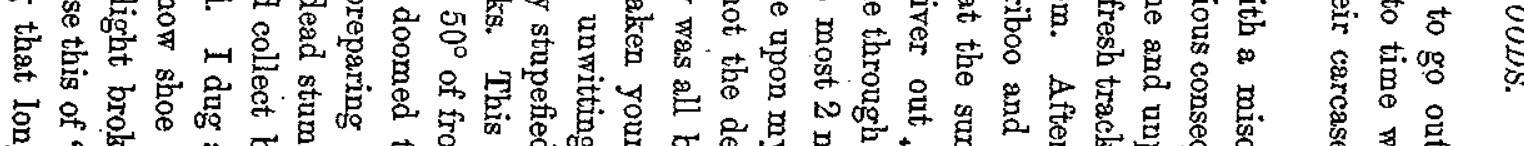
积 三

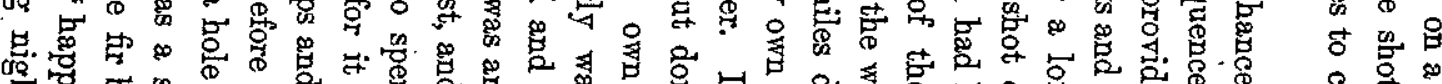

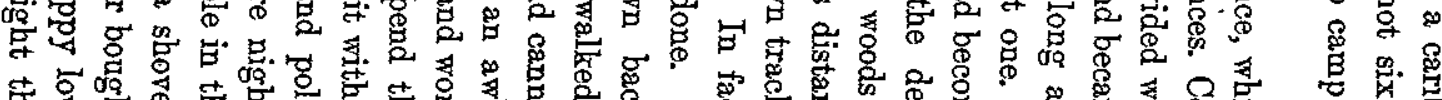

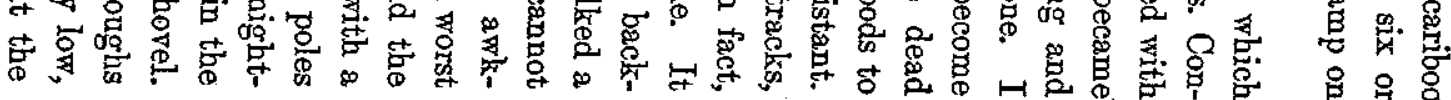




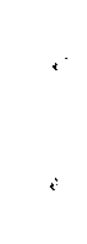




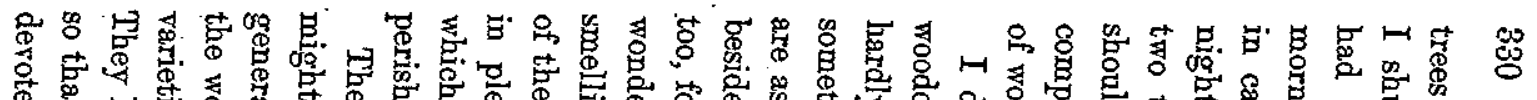

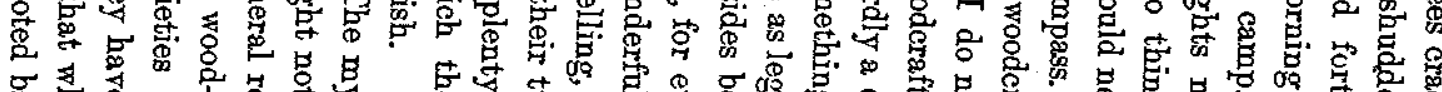

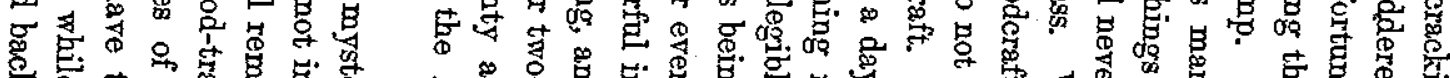

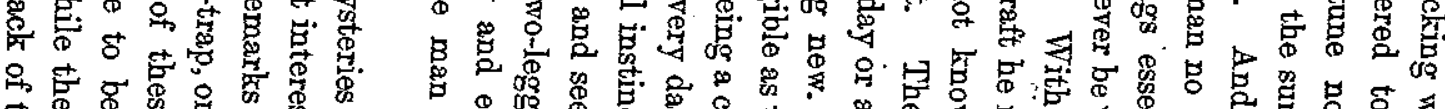

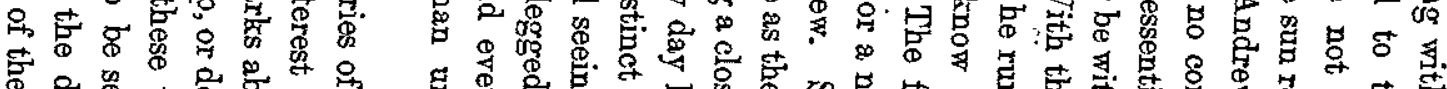

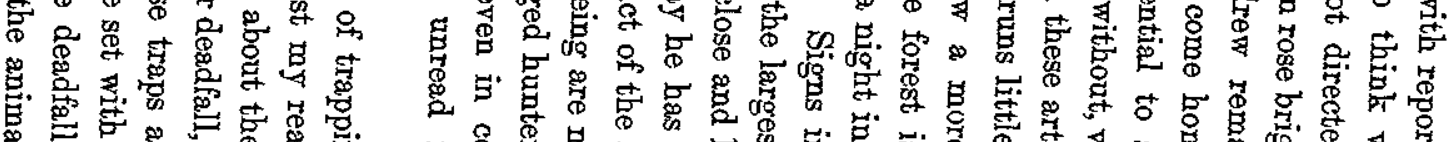

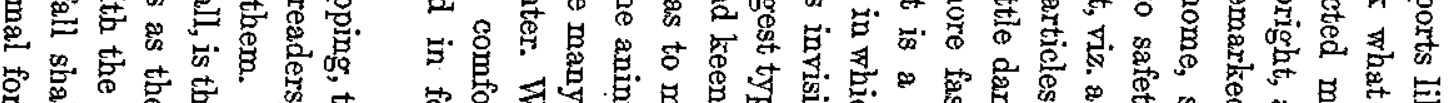

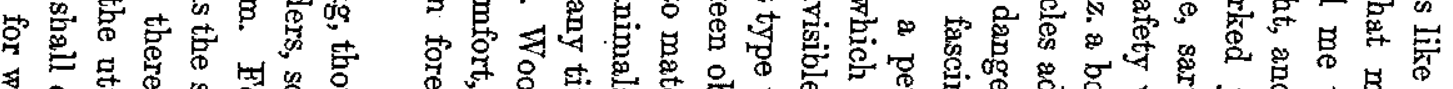

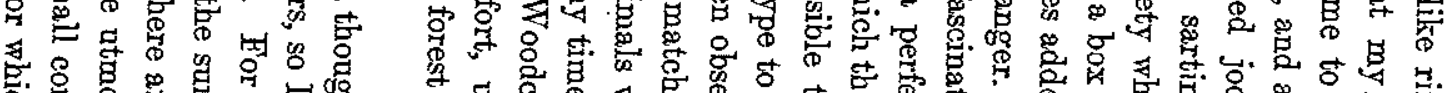

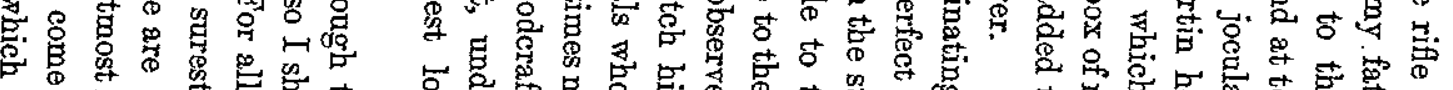

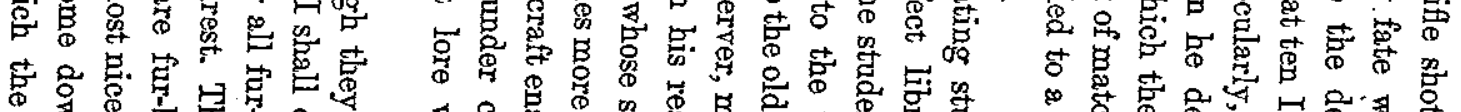

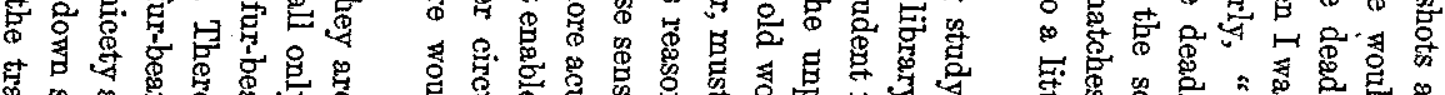

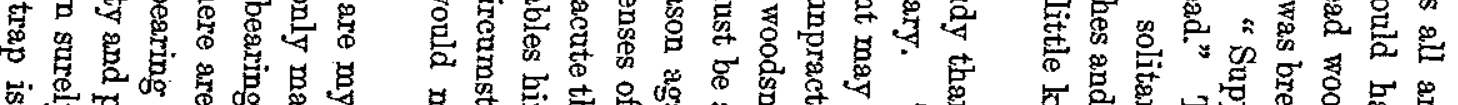

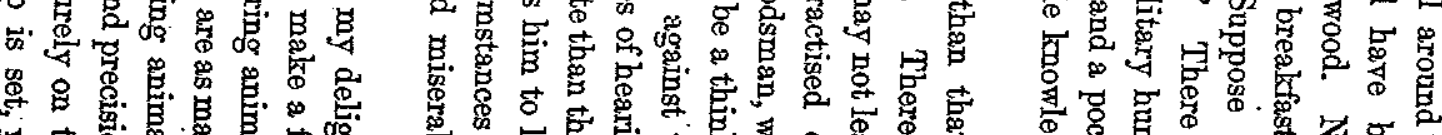

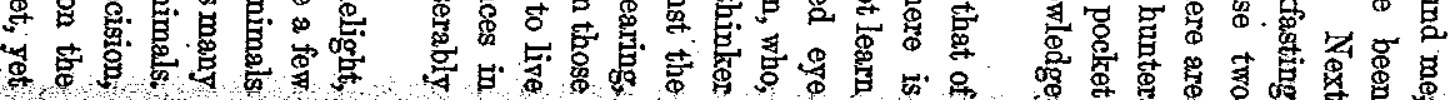

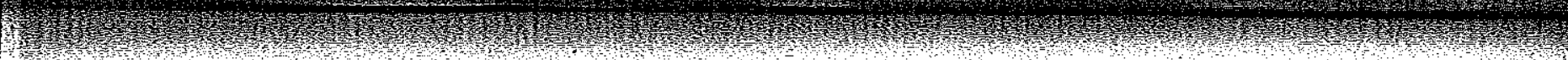

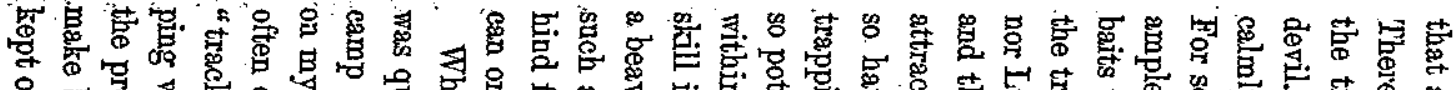

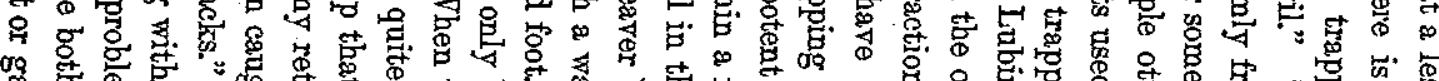

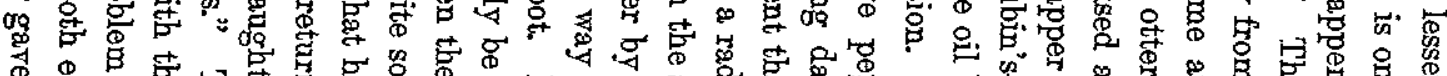

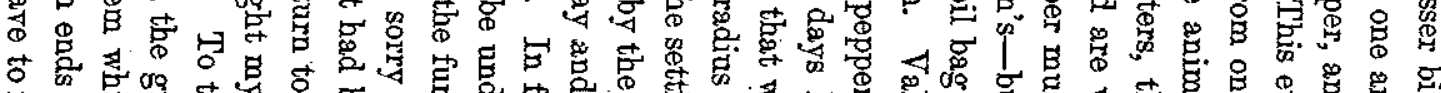

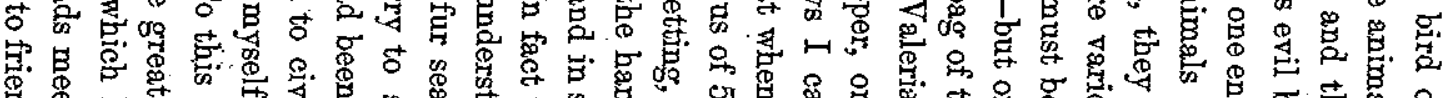

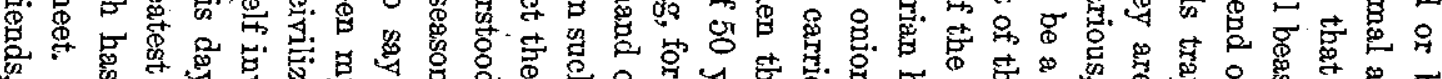

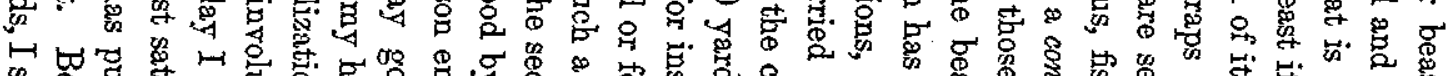

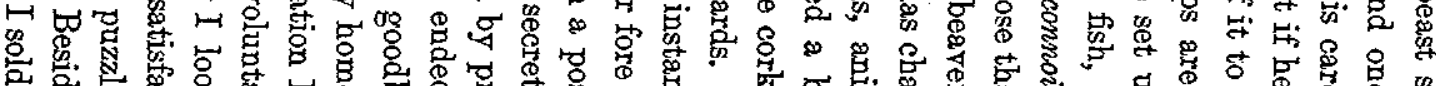

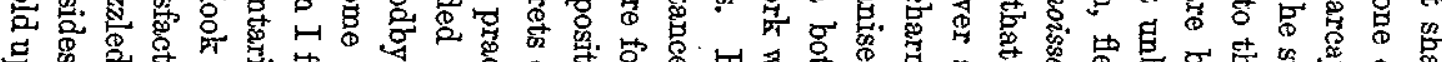

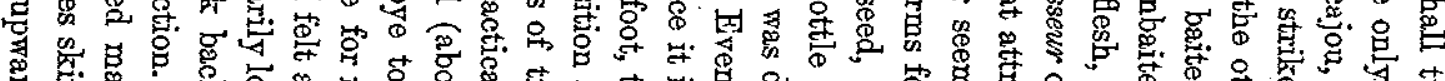

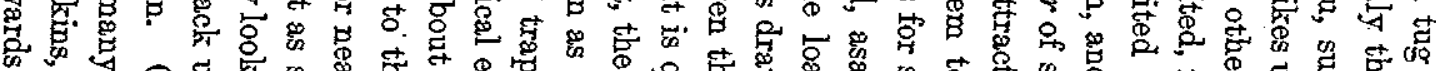

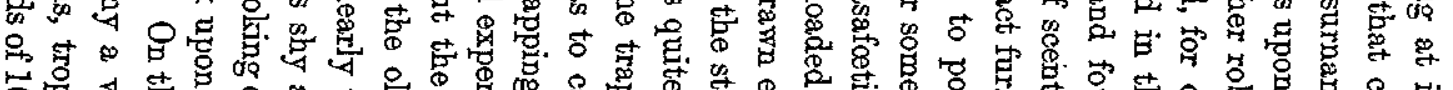

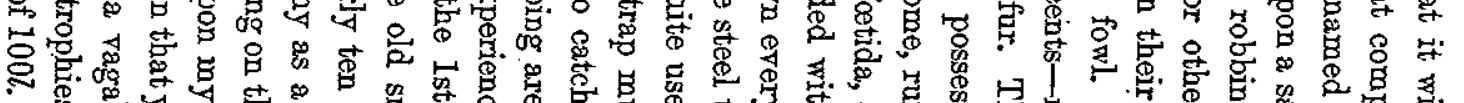

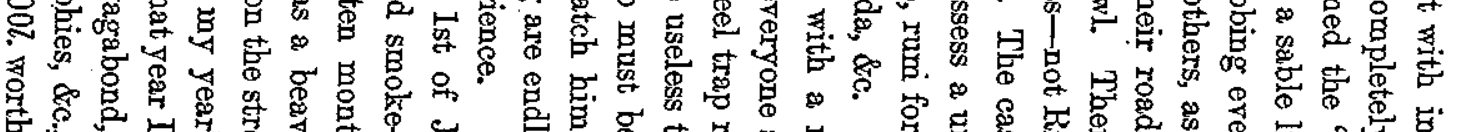

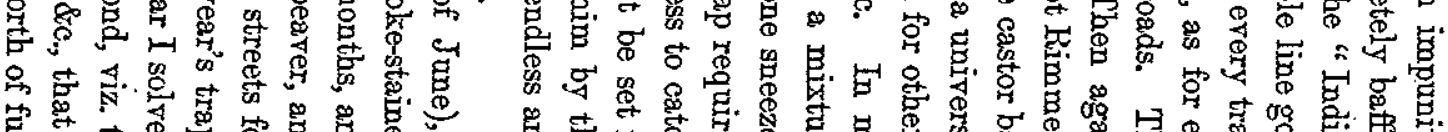

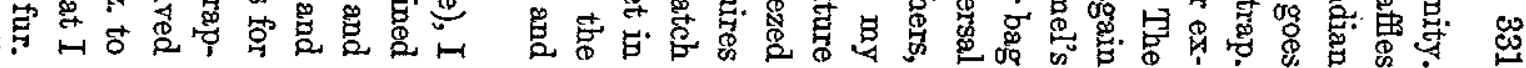




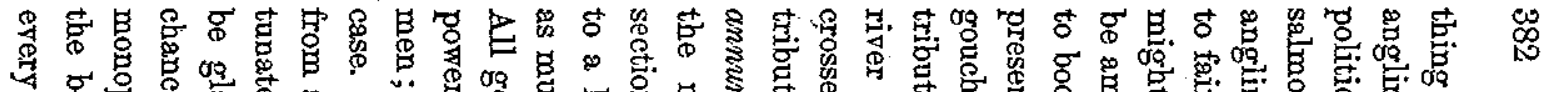

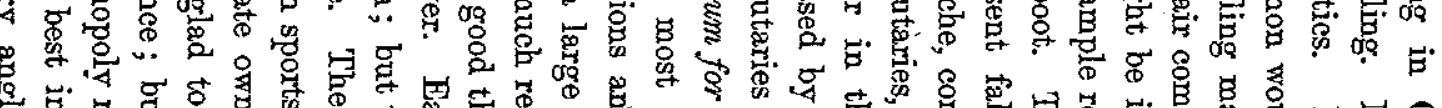

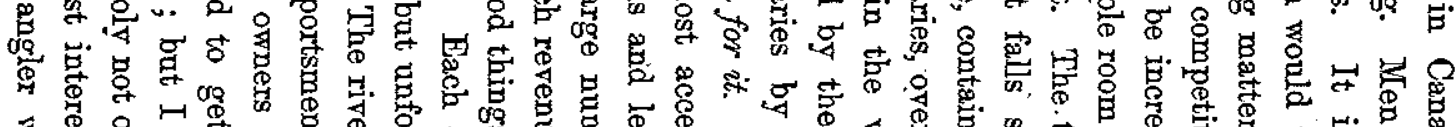

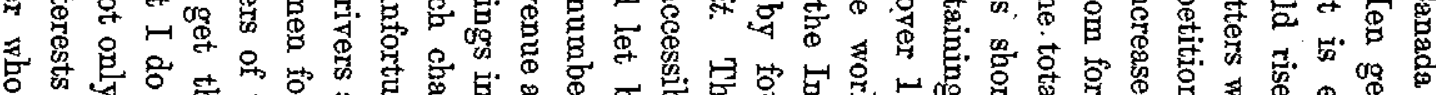

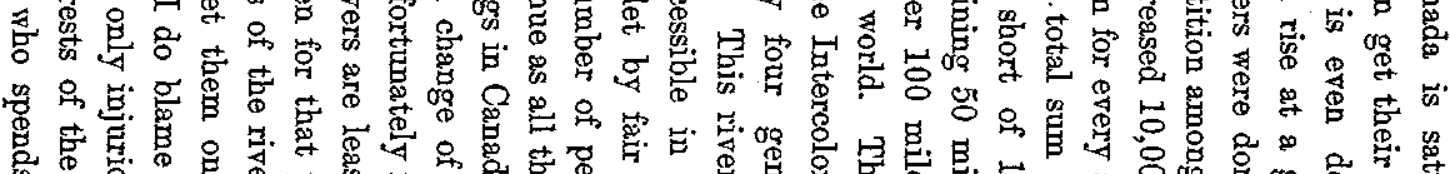

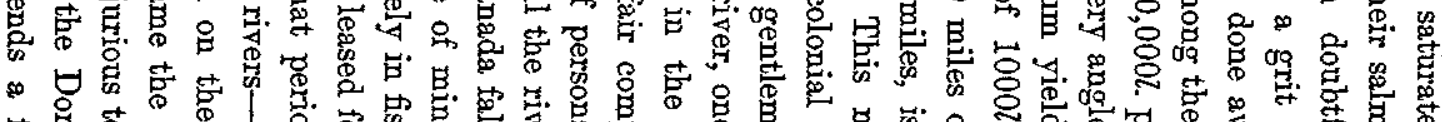
宫范

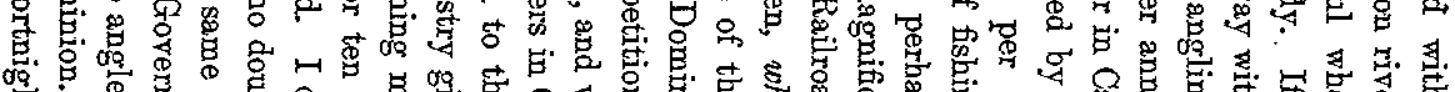

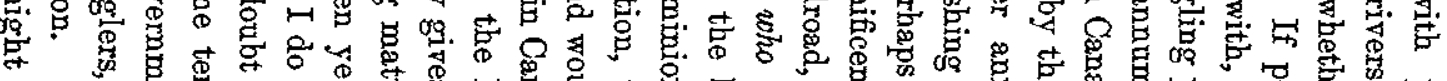

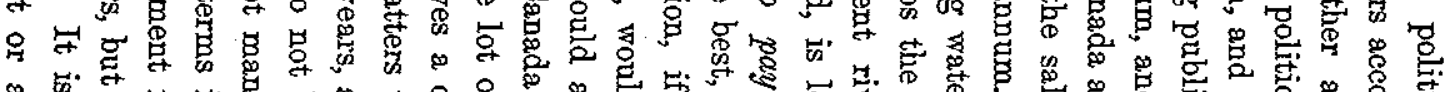

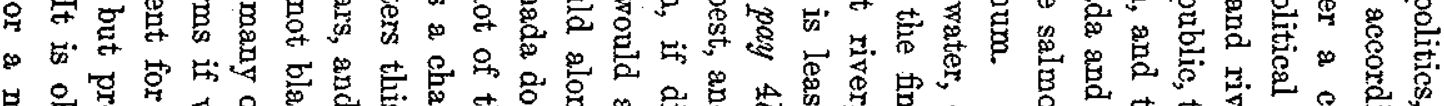

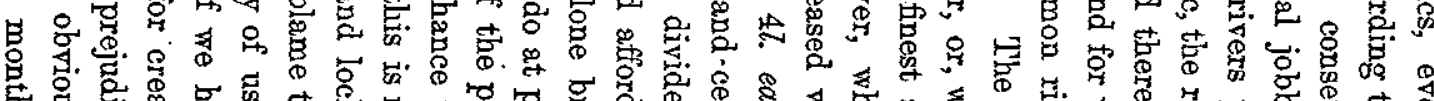

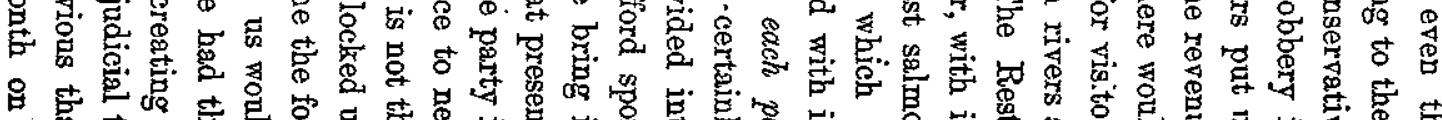

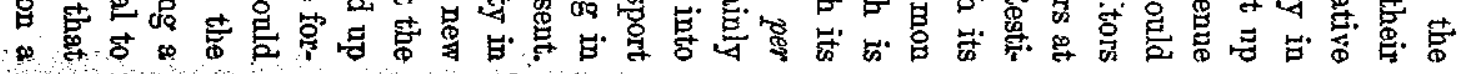

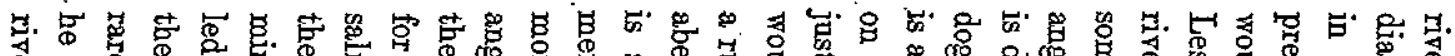

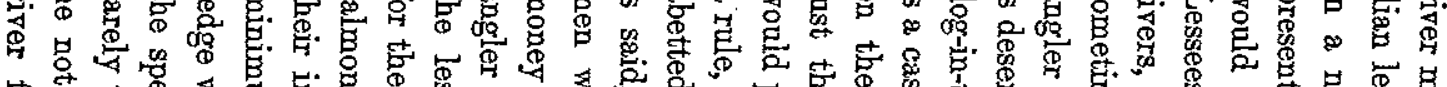

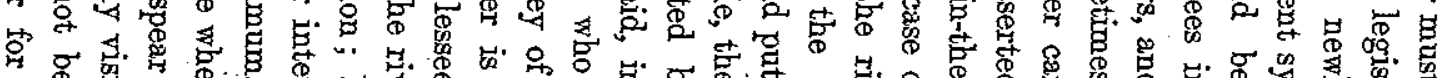

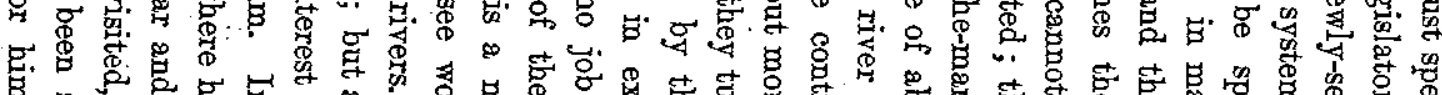

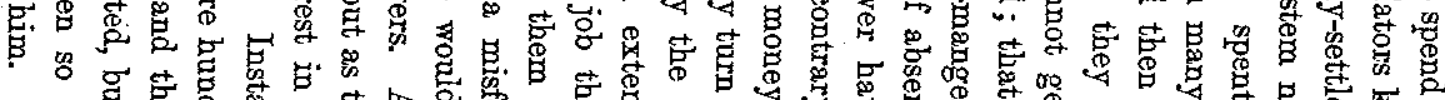

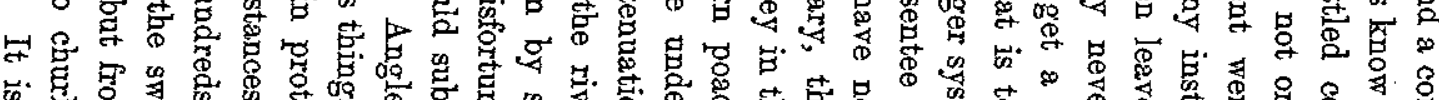

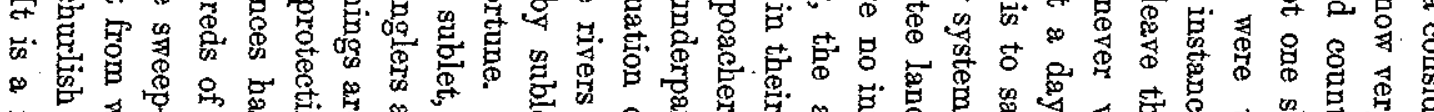

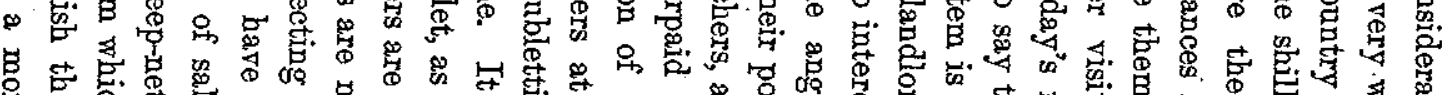

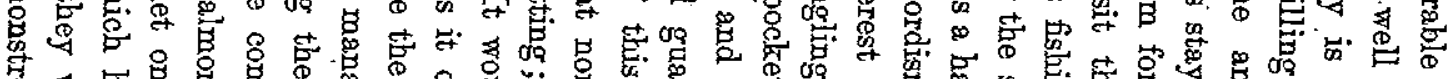

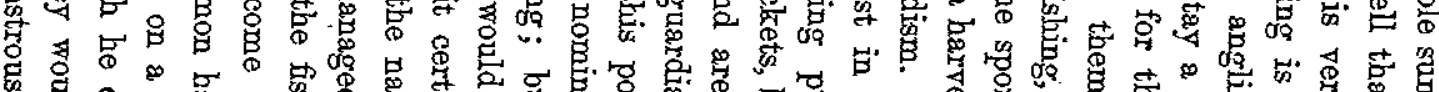

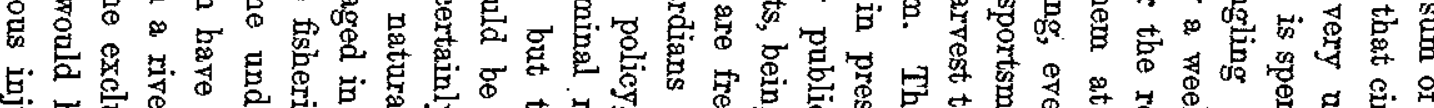

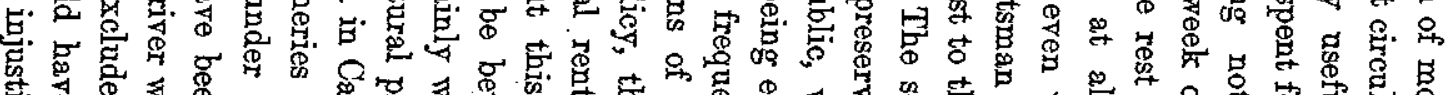

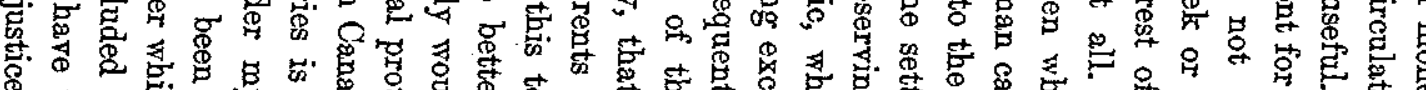

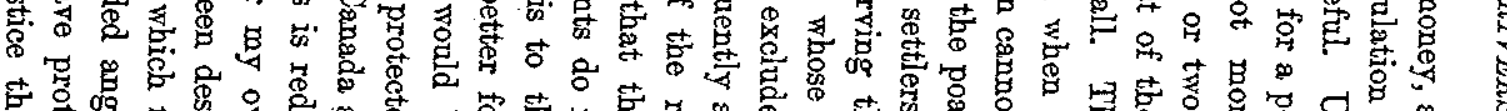

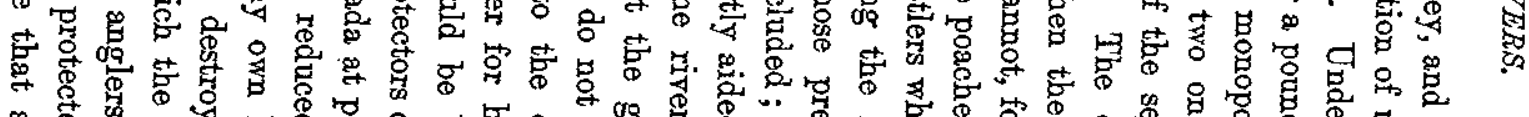

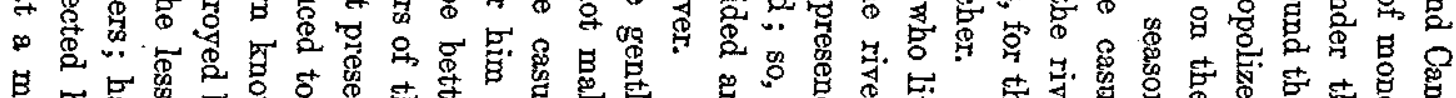

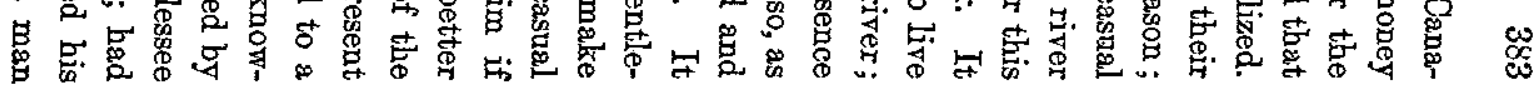




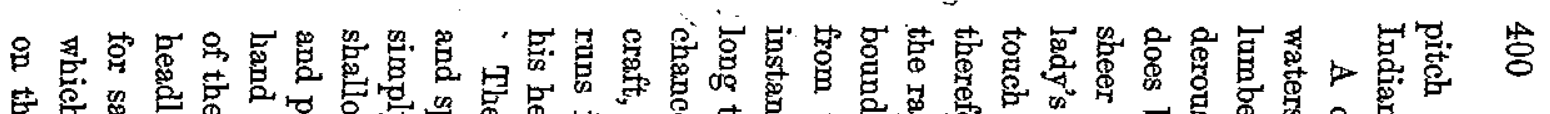

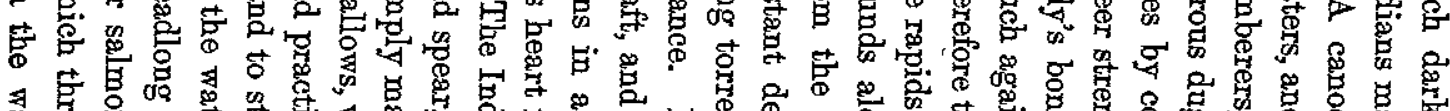

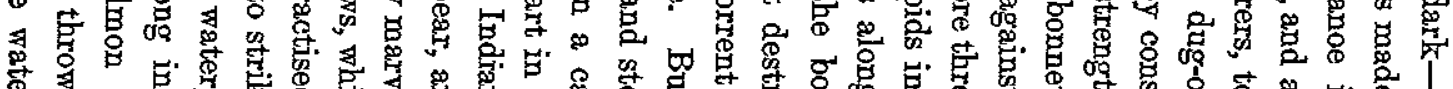

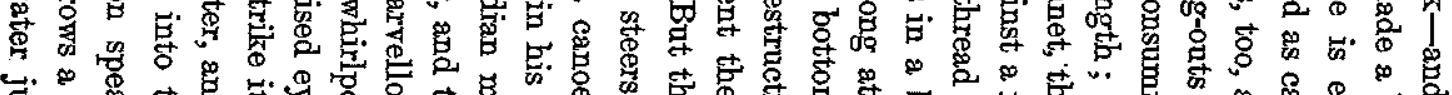

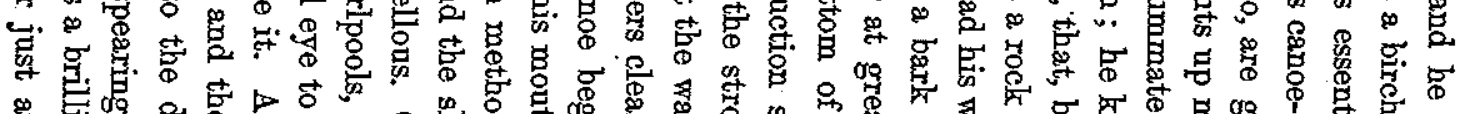

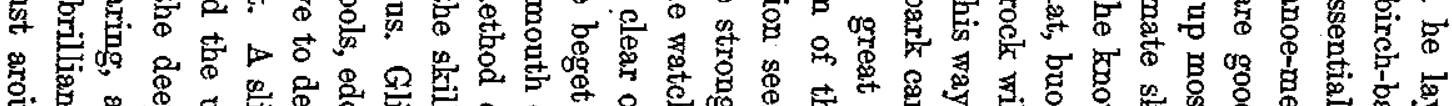

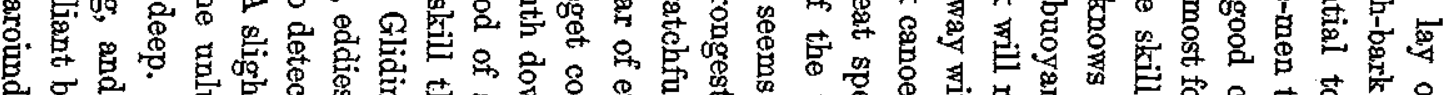

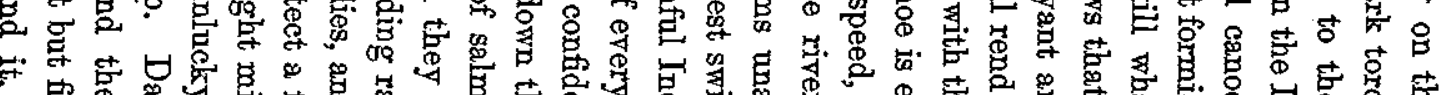

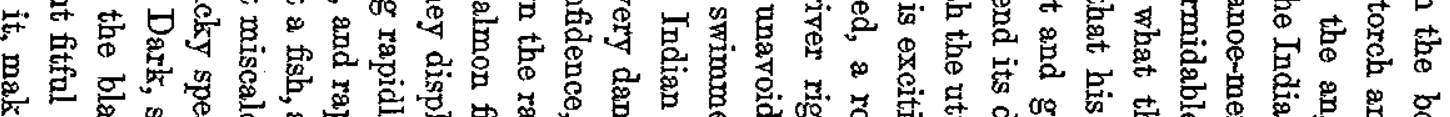

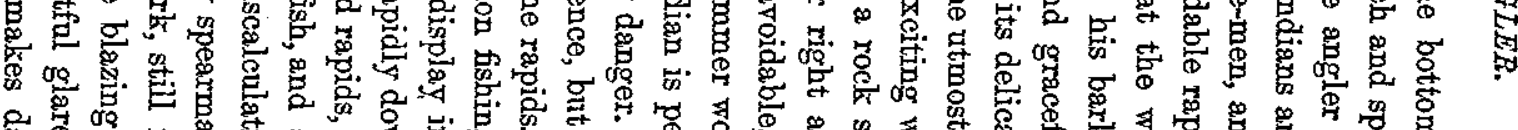

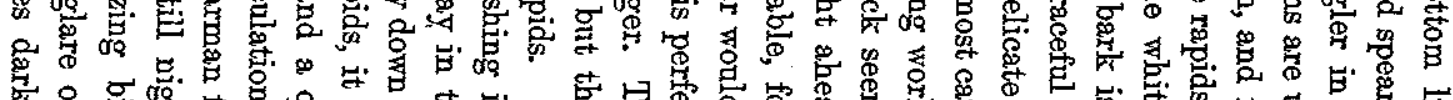

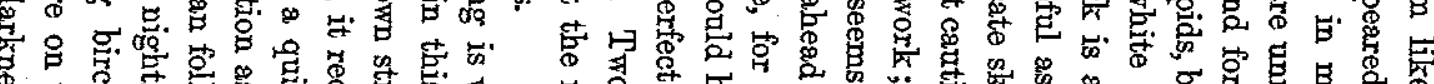

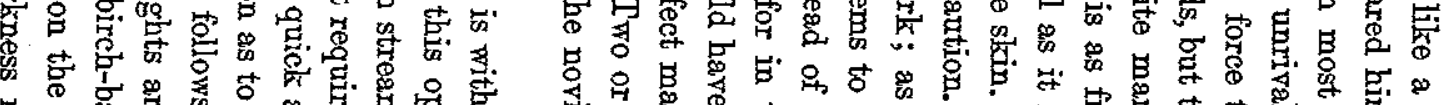

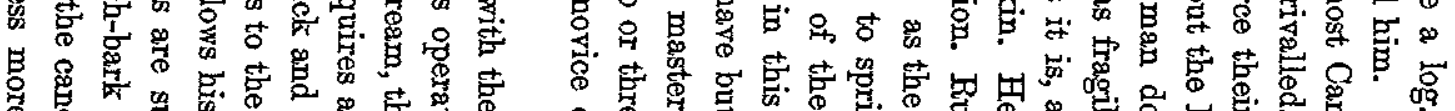

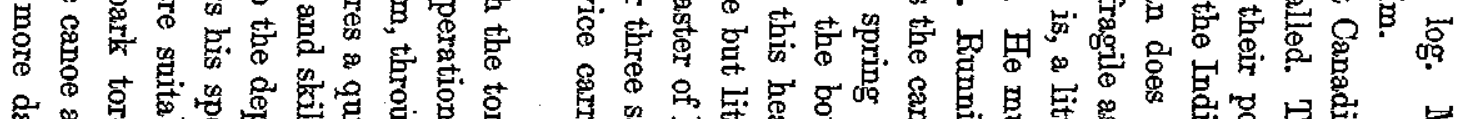

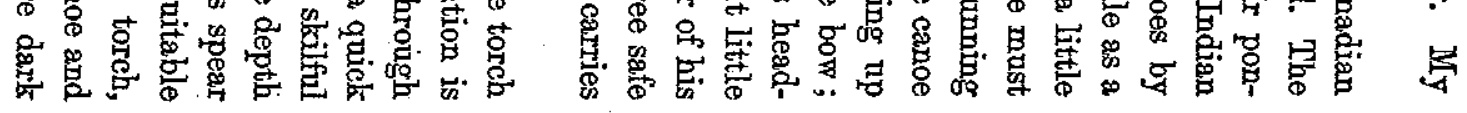

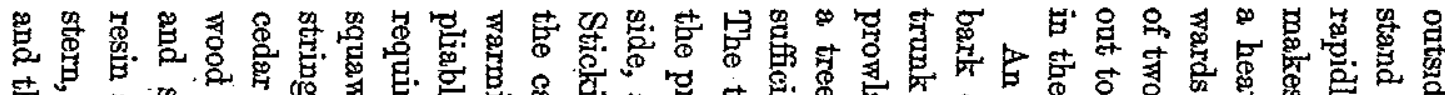

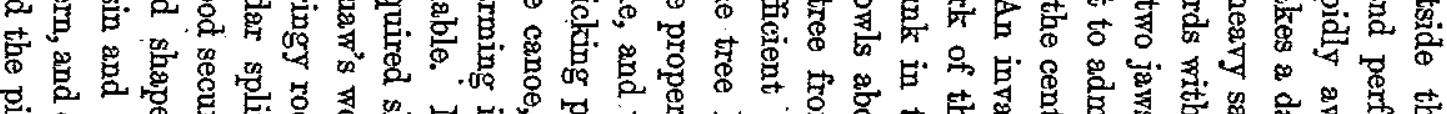

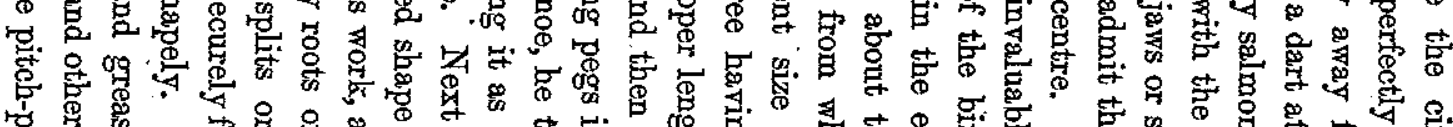

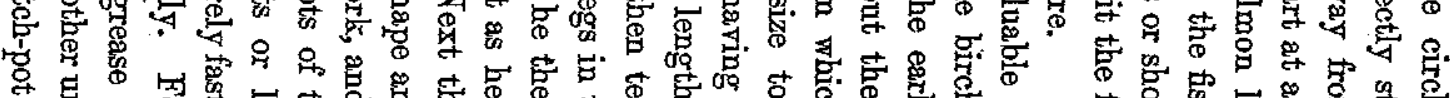

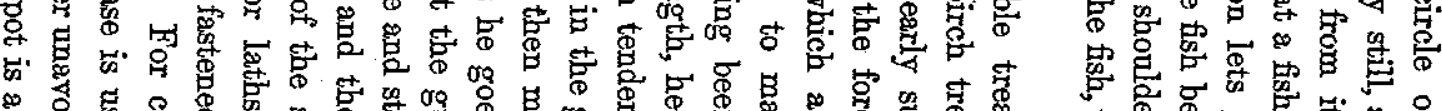

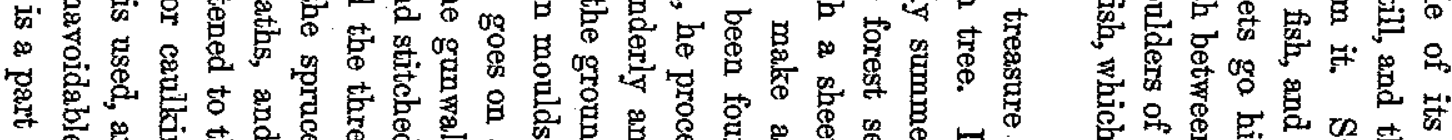

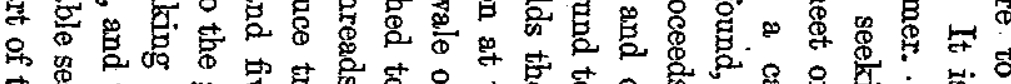
声旡

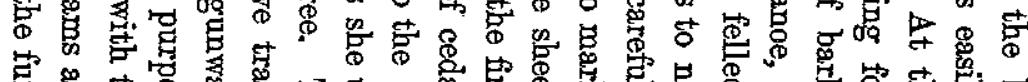

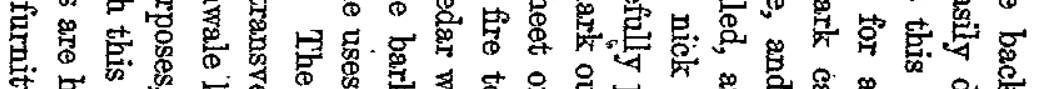

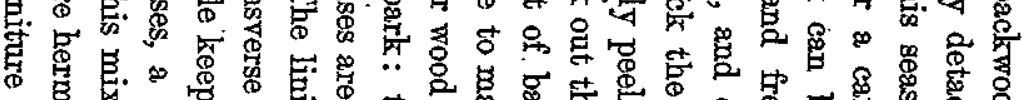

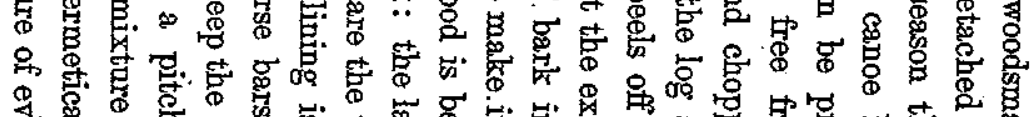

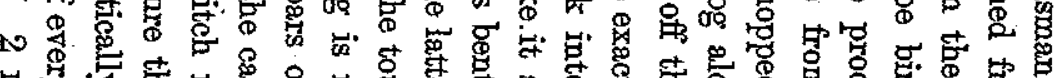

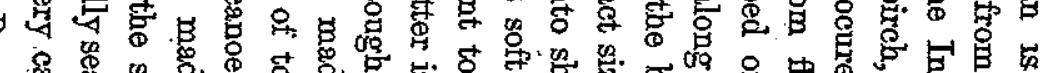

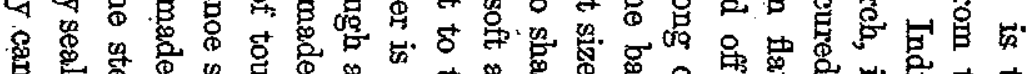

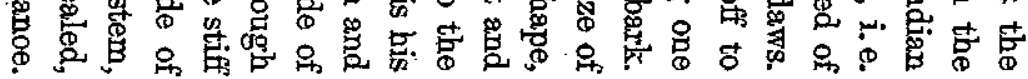

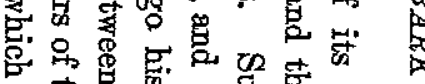

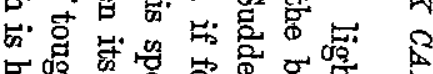

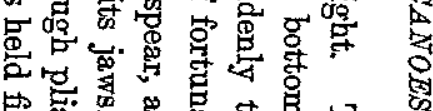

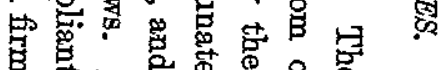

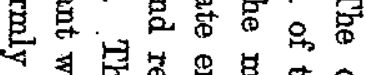

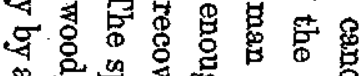

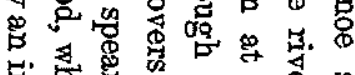

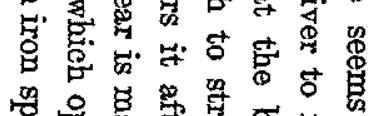

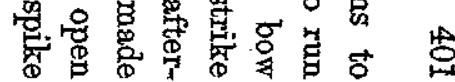




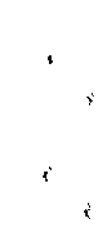




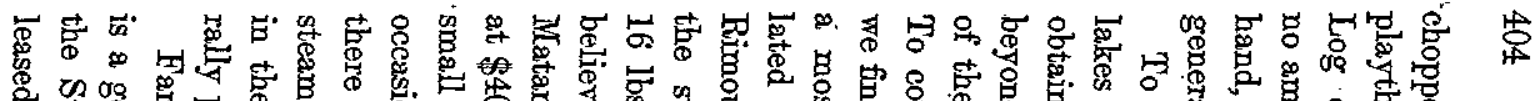

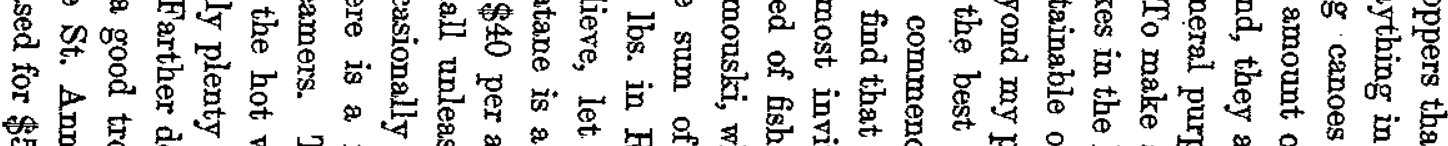

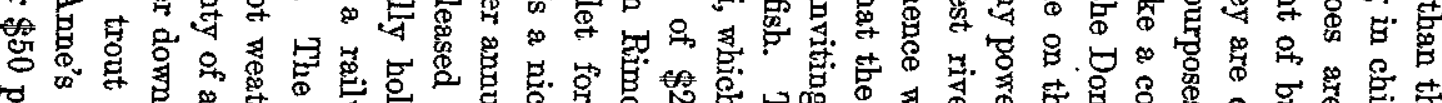

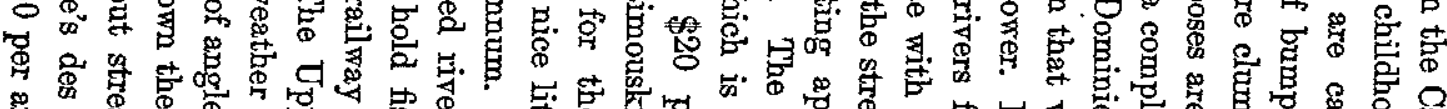

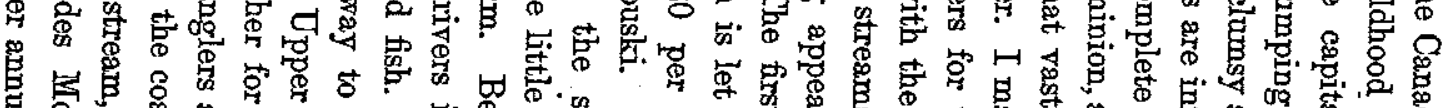

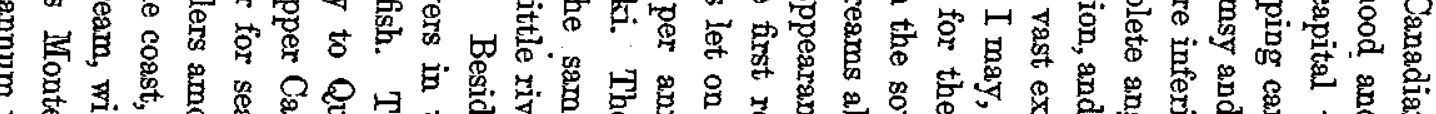

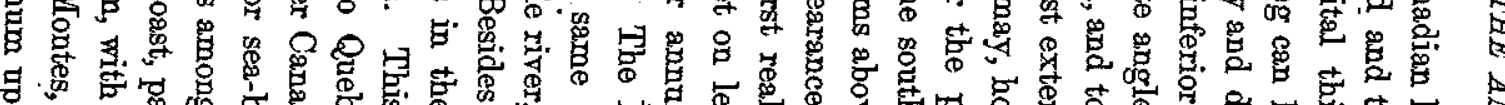

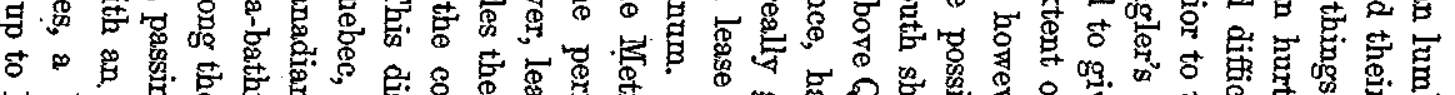

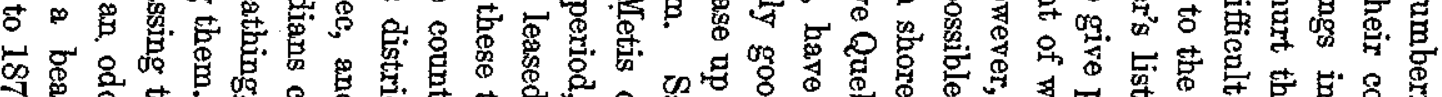

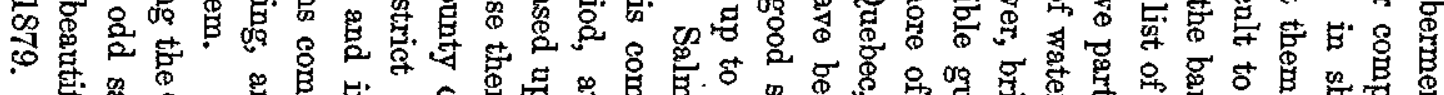

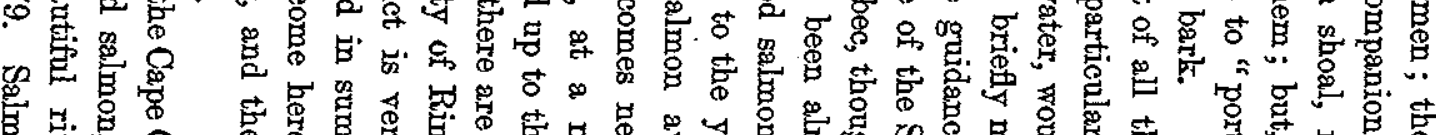

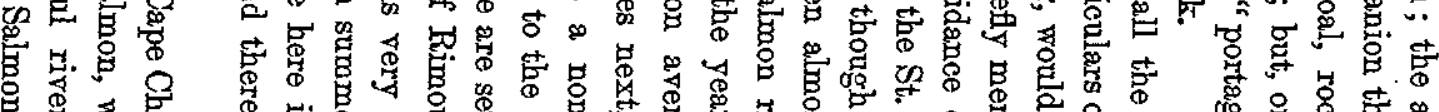

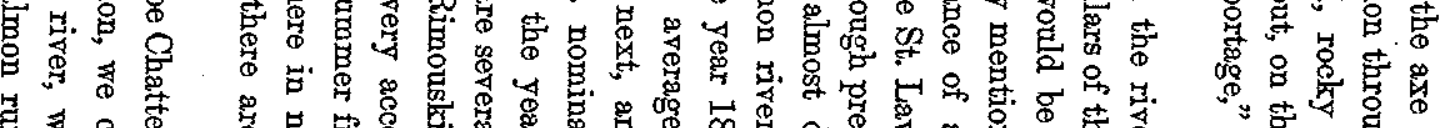

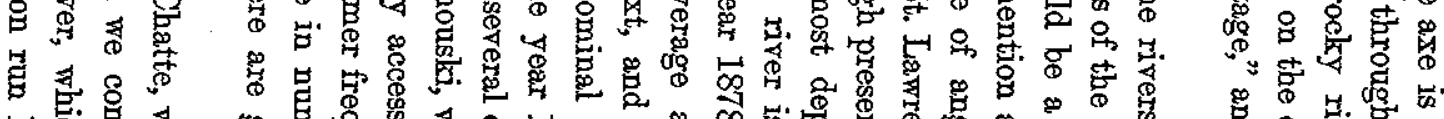

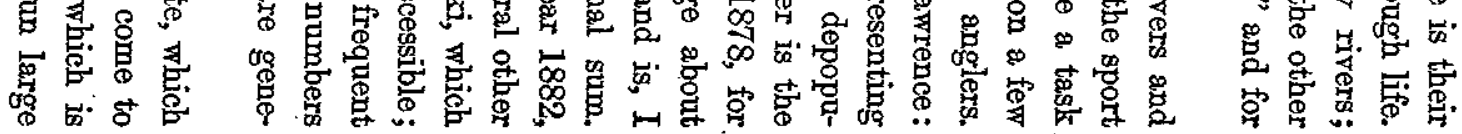

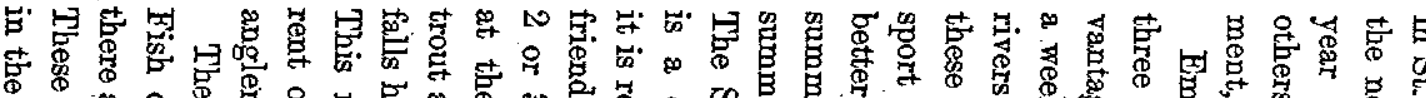

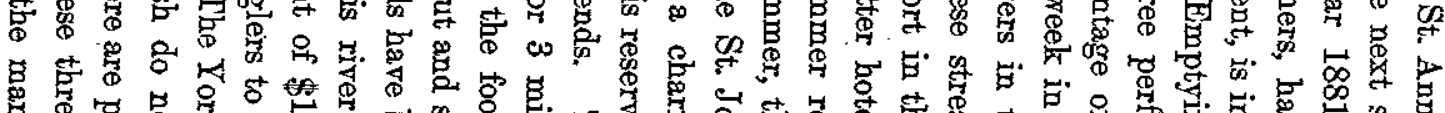

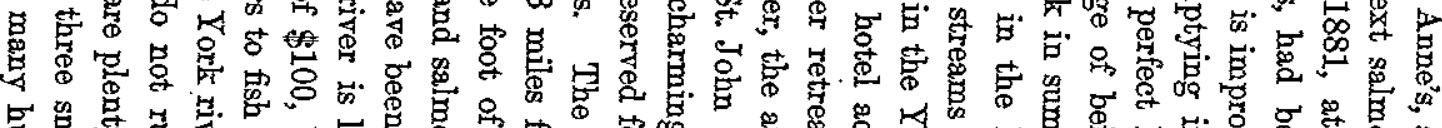

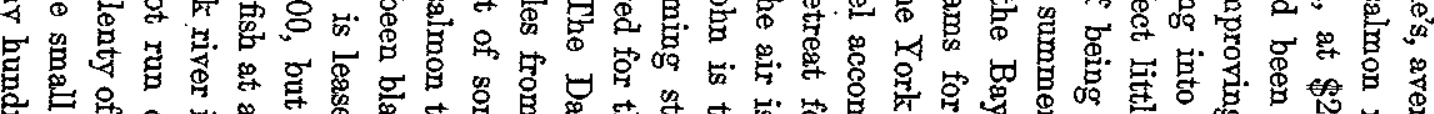

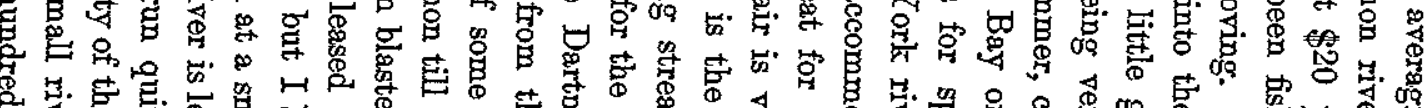

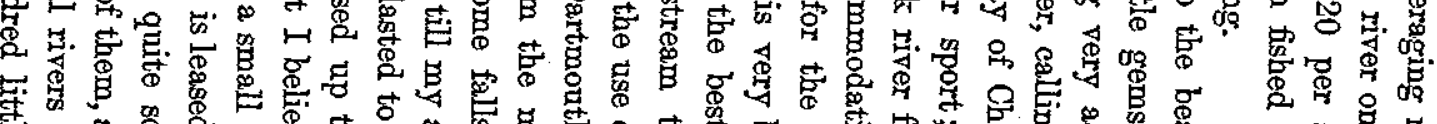

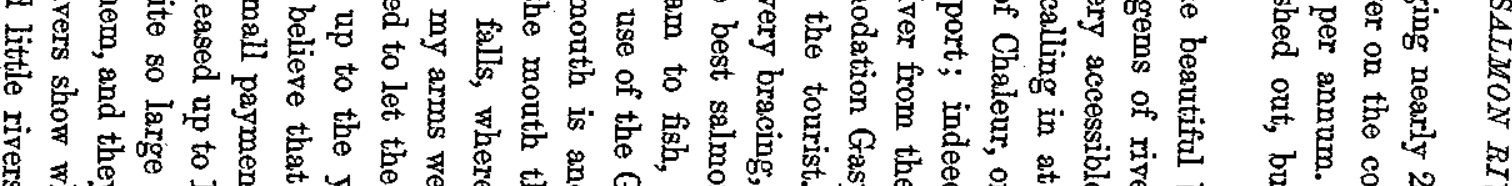

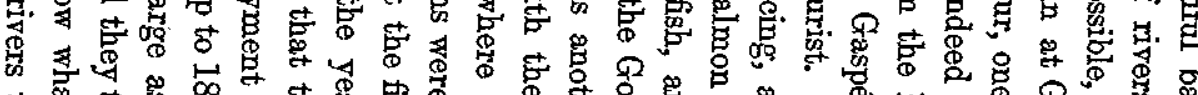

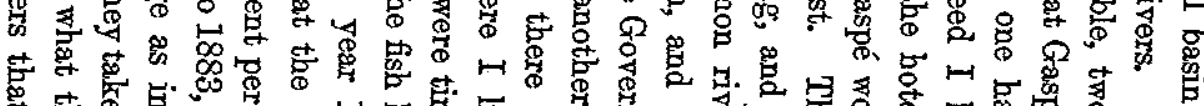

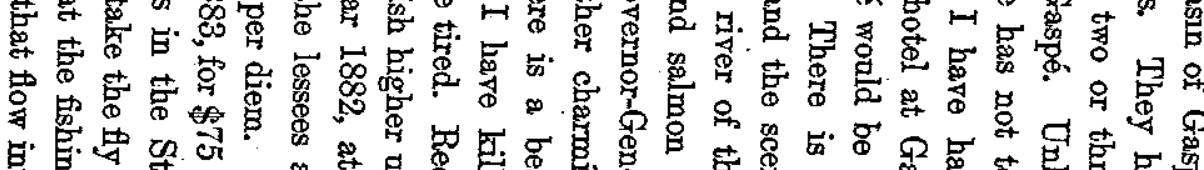

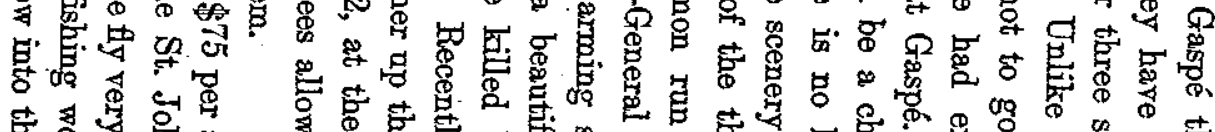

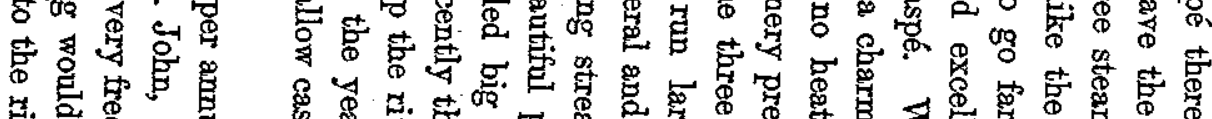

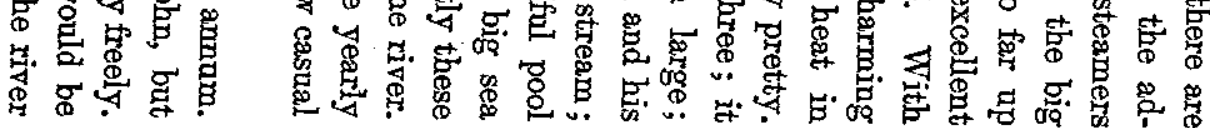

进 8

目墨客

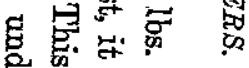
苟落 品急. 兽

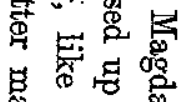

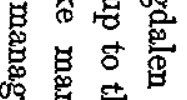

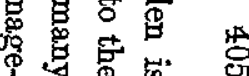


